\title{
Socio-Spatial Changes in Danwei Neighbourhoods: A Case Study of the AMS Danwei Compound in Hefei, China
}

\author{
Nanqi Ye*(D), Michihiro Kita $\mathbb{D}$, Shigeki Matsubara, Seth Asare Okyere $\mathbb{D}^{\mathbb{D}}$ and Motoki Shimoda \\ Division of Global Architecture, Graduate School of Engineering, Osaka University, Suita 565-0871, Japan; \\ kita@arch.eng.osaka-u.ac.jp (M.K.); shigeki@arch.eng.osaka-u.ac.jp (S.M.); \\ seth_asare_okyere@arch.eng.osaka-u.ac.jp (S.A.O.); shimoda@arch.eng.osaka-u.ac.jp (M.S.) \\ * Correspondence: ynq1990@gmail.com
}

check for updates

Citation: Ye, N.; Kita, M.; Matsubara,

S.; Okyere, S.A.; Shimoda, M.

Socio-Spatial Changes in Danwei Neighbourhoods: A Case Study of the AMS Danwei Compound in Hefei, China. Urban Sci. 2021, 5, 35. https:// doi.org/10.3390/urbansci5020035

Academic Editor: Stefan Anderberg

Received: 21 February 2021

Accepted: 9 April 2021

Published: 12 April 2021

Publisher's Note: MDPI stays neutral with regard to jurisdictional claims in published maps and institutional affiliations.

Copyright: (c) 2021 by the authors. Licensee MDPI, Basel, Switzerland. This article is an open access article distributed under the terms and conditions of the Creative Commons Attribution (CC BY) license (https:// creativecommons.org/licenses/by/ $4.0 /)$.

\begin{abstract}
This paper analysed socio-spatial changes in old urban neighbourhoods (Danwei compounds) in Chinese cities as a result of two major national level reforms: the Reform and Opening Up and the Urban Housing reform in 1978 and 1997, respectively. Existing research indicates fundamental changes have taken place in the political, economic and social aspects of Danwei compounds. However, there is a paucity of research on micro-level changes. To understand how these reforms have affected the social-spatial schema of Danwei Compounds, the study utilised mapping, key person interviews and field observation in AMS compound, Hefei city of Anhui province. This paper compared the AMS Danwei Compound before and after the reforms in terms of public spaces, building features and compound management. The study found that the AMS Danwei Compound has experienced a significant reduction in public space, an increase in building density and a reconfiguration of compound management actors. The study suggests the need for local planning authorities and government to pay attention to planning and design of the old city core by emphasising improvement in public spaces, attention to compact design principles for urban neighbourhood planning, and establishment of local community management body.
\end{abstract}

Keywords: Danwei; working unit; urban community; neighbourhood; public space; neighbourhood management; urban planning; China; reform; historical comparison

\section{Introduction}

The 'Danwei' system, also known as the 'working unit', is a unique community-level socio-spatial system which emerged after the founding of the People's Republic of China (PRC) in 1949. The Chinese word 'Danwei' is the collective term for non-natural person entity unit of human society. 'A Danwei' could refer to, for example, a school, a hospital, a government institution, a factory, etc. The Danwei system was established to obtain the national mobilisation ability to rebuild the economy and industrialised productivity [1]. It is generally considered that this system contributed enormously to the physical shape of Chinese cities, in addition to the economic, political, social and spatial structure of modern China, particularly during the 20th century. In spatial terms, the Danweis are physically identified as Danwei compounds: a gated work-life mixed neighbourhood enclosed by walls [2]. The interior is often a mix of offices, residential and public facilities with various spaces and facilities for the employees' working, housing, catering, and even recreation, sports, fitness, and basic medical care. For a long time after its establishment, it had been the basic unit of urban neighbourhood construction [3].

However, after the 1990s, some changes began to occur in the compounds due to the decline of the macro socio-spatial system it was based on. This decline was fuelled by two of the most significant Chinese reforms of the second half of 20th century-the Reform and Opening Up (1978) and the Urban Housing Reform (1997). On the one hand, the Reform and Opening Up, which began in 1978, loosened the economic and social structure base of the Danwei system with significant effects on space, society and economy [4]. 
Prior to this reform, China implemented a planned economy system in which most public goods were rationed [5]. In this planned system, the entire society was de-monetised and hence had no free market in which goods could be bought and sold freely with money. Thus, urban residents were required to be part of a government-recognised organisation or institution (a Danwei) in order to get access to industrial or agricultural products [6]. This system tied all citizens onto the same social system, forming a single community of interest. However, this so-called class-neutral planned economy led to a low level of productivity and other social problems, such as the urban-rural dualism, and hence necessitated the need for reforms [7]. As a result, The Reform and Opening Up was launched in 1978, which among other things, led to the reversion of private ownership, and the use of currency to buy and sell goods [5]. On the social front, the notion of China as one original 'single community' was dismantled, allowing the population to have free mobility across the country. Consequently, social organisations independent from the Danwei system proliferated after 1978. However, due to historical inertia, a slow integration of marketbased society and the apparent contradiction between the goal of the reform and the local realities, the Urban Housing reform was not introduced until 1997.

The Urban Housing reform, on the other hand, is considered to have particularly impacted the spatial base of the Danwei compound. It was a top-down reform of housing and urban land-use. Before this reform, all urban land and housing resources belonged to the State and could not be traded [8]. Typically, the government would allocate the rights of land use to Danweis, while the ownership and title to the land remained with the State. A Danwei would build a compound and thus control the land and houses. After the Urban Housing reform in 1997, the property rights of the residential houses in the Danwei compounds were distributed to individual occupants, leading to the gradual loss of the Danwei's (organisational entity) control over its territory. Expectedly, this resulted in the creation of a new real estate market, permitting individuals to own homes as assets (while land ownership remained with the State) [8]. While the above reforms contributed to rapid economic growth, they have also unleashed a fundamental transformation of the social and spatial structure of Chinese cities [9]. Unfortunately, the constituent changes in Danwei compounds' socio-spatial system impacted by these reforms have not attracted relevant empirical attention in the scholarly literature. Previous studies of Danwei system and Danwei compound have looked at historical [10,11], political [7], economic [12] and social [9] aspects of the Danwei. However, most of these studies focus on the city-wide scale rather than the micro level of the neighbourhood or compound. The few studies that focus on the micro-level do not provide a historical context for socio-spatial changes. For example, Peiling [13] studied the micro-level features of the Jingmian Danwei compound in Beijing, which revealed dislocated identities in the socio-spatial relationships among residents without engaging the historical context of the reforms. This is also true for the study of Zhang et al. [14] on the spatial changes of a Beijing Danwei compound by analysis its maps between the 1990s and 2006.

To fill the research gap of socio-spatial change studies of Danwei compounds, this study uses a time domain comparative approach. The study is guided by the question of: what are specific social and spatial changes in Danwei compound after the reforms. By comparing the socio-spatial elements of a Danwei compound at different time periods, the study clarifies the changes which have taken place within the compound. This study assumes that such analysis can shed useful insight on challenges and potentials for effective community level planning at this critical stage of urban development in old Chinese cities. From the perspective of urban planning-and in the context of China's current urban transformation and rapid urban renewal planning of old city cores-effective locally oriented planning and spatial development warrants analysis of the socio-spatial changes that have emerged due to the reforms have shown their imperativeness and necessity. This study is therefore, an extension of earlier studies on Hefei city and Danwei compounds by the authors $[15,16]$. 
The paper is organised into six sections. Section 2 explains the conceptual and analytical framework of this paper. Following by Section 3 presents the methodology, while Section 4 presents results. Sections 5 and 6 present the discussion and conclusion, respectively.

\section{Socio-Spatial Changes in Urban Neighbourhoods: A Framework}

Since its inception in the 20th century, the concept of the 'neighbourhood', the basic unit of urban habitat, has embodied the dual meaning of urban geographic space and human life [17]. In other words, a 'neighbourhood' is a complex that encompasses both the internal physical space, such as buildings, roads, open spaces and public facilities, and the internal social elements, such as interpersonal relations, community structures, economic flows, and the maintenance and management of facilities. Particularly in urban studies, the 'neighbourhood' has been characterised as a Socio-Spatial Schema in order to precisely perceive and explain the concept of 'community' locally $[17,18]$. This framing allows scholars and practitioners to better comprehend the neighbourhood as a whole or in it constituent parts by deconstructing into smaller, measurable elements which can be observed and assessed. In other words, the urban neighbourhood can be considered as a socio-spatial unit of human habitation with constituent but interrelated parts that are usually in constant interaction [19].

The conception of the urban neighbourhood as a socio-spatial schema allows for qualitative or quantitative description of a particular community in several analytical dimensions. For example, Gür and Enön used various qualitative and quantitative methods for measuring the significance of various social and spatial elements in neighbourhood design and verified the inseparability between these elements [20]; Sykora used several methods such as mapping, quantitative statistics and qualitative description for different elements in their study of neighbourhood differentiation in Prague [21]; in their study of the relocation of a neighbourhood in İzmir, Turkey, Eranil et al. mainly adopted interview and field observations to collect and describe changes in various socio-spatial elements in great details before and after the relocation of the neighbourhood [22]; He and Wu used qualitative descriptions, quantitative statistics and other methods to collect information in their framework, while incorporating logistic regression and other methods to discuss the changes in socio-spatial elements of two different types of neighbourhoods in Shanghai, China under the context of property-led redevelopment [23].

Indeed, the use of mixed methods in analysing and comprehending urban neighbourhoods as socio-spatial units helps to bridge the scaling gap between community studies and urban studies at the conceptual and methodological level. In addition, it unravels the mechanisms and processes involved in urban development and changes. For example, Sykora [21] chose three elements of income, housing system, social mobility and migration in this framework to study neighbourhood differentiation and changes all across the city of Prague in its post-communist transition. Additionally, by using the Factor Ecological Analysis and Hierarchical Cluster Analysis, Wang and Liu [18] analysed the evolution of urban social space and its mechanisms in the city of Xi'an, China. Moreover, He [23] examines the evolving of enclave urbanism in community and urban development in the city of Guangzhou, China in this framework.

In the extant literature, the common use of the socio-spatial framework is to first select a number of measurable socio-spatial elements and to build a structural framework for describing the neighbourhood; then to obtain a qualitative or quantitative description of the elements through various research methods; and finally to synthesise the descriptions of these elements into a coherent picture of the community. This method is often used for comparative studies between different neighbourhoods over the same period of time. For example, in the study on socio-spatial differentiation and residential inequalities in the residential restructuring process in Shanghai, $\mathrm{Li}$ and $\mathrm{Wu}$ [24] firstly build a cascading framework by the elements of social stratification, residential stratification, housing tenures, neighbourhoods and socio-spatial transformation. Then, a case study of three neighbourhoods was implemented to collect spatial, demographic, socio-economic and housing data 
for the discussion of the framework noted above. In the same research, they also compared different neighbourhoods' socio-spatial elements by logistic regression while confirming the gentrification of central city neighbourhoods. Other scholars employ socio-spatial framework of urban neighbourhoods in comparative studies of the same community at different times. For example, Eranil et al. [22] studied the relocation of Kadifekale inhabitants to TOKI Uzundere in İzmir. They used interviews and field surveys to describe the changes in the spatial aspects and social aspects of the community before and after the relocation, using a large number of photographs, descriptions of the inhabitants' life scenes and interview transcripts. Specifically, in spatial aspects their research concluded that the disappearance of flexible common spaces and the use of multi-storey apartment housing caused the shrinkage of public life, the loss of common defensive space led to the elimination of children's play space, and the replacement of small local shops by shopping centres and the changes in the way coffee shops being used made public life in the community less accessible and less frequent. At the same time, they examined changes in migration, traditional values, social solidarity, olfactory recognition and social bonding in social aspects. Finally, after studying these elements, they evaluated the relocation as "the project implementers failed to consider the residents' accustomed home-neighbourhood environment and communication zones" and caused the residents to be separated from their neighbourhood physically and consequently become fragmented socially. Table 1 provides details about some of the common socio-spatial elements analysed in existing literature that frames the urban neighbourhood as a socio-spatial unit of human habitation often in processes of change.

Table 1. Neighbourhood studies using a socio-spatial schema.

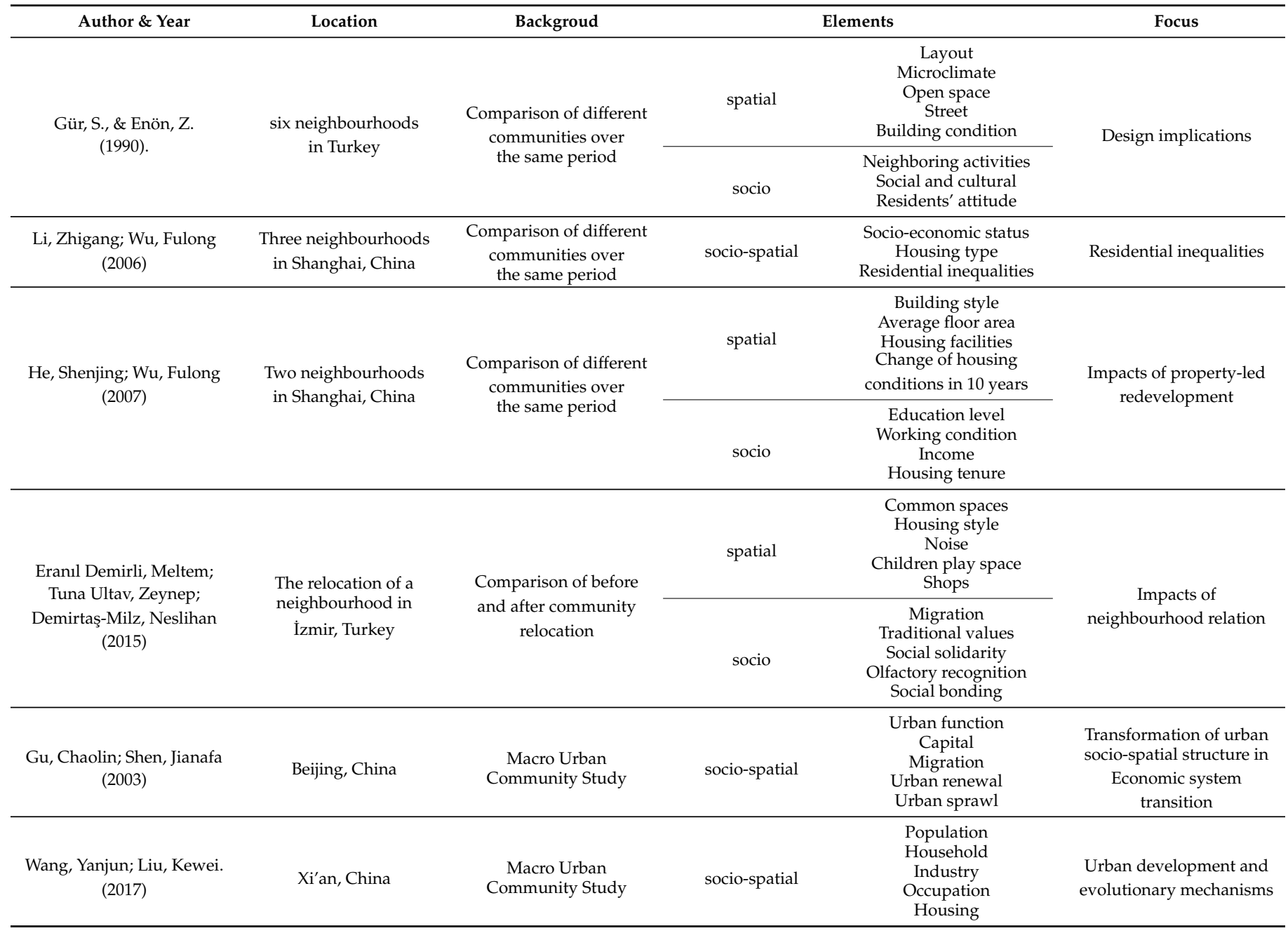


Table 1. Cont.

\begin{tabular}{|c|c|c|c|c|c|}
\hline Author \& Year & Location & Backgroud & \multicolumn{2}{|c|}{ Elements } & Focus \\
\hline $\begin{array}{c}\text { Sykora, Ludek. } \\
\text { (1999) }\end{array}$ & Prague, Czech Republic & $\begin{array}{c}\text { Macro Urban } \\
\text { Community Study }\end{array}$ & socio-spatial & $\begin{array}{c}\text { Income } \\
\text { Housing system } \\
\text { Social mobility \& } \\
\text { migration }\end{array}$ & $\begin{array}{c}\text { Post-communist } \\
\text { transition and Socio- } \\
\text { spatial Differentiation }\end{array}$ \\
\hline $\begin{array}{l}\text { He, Shenjing } \\
\text { (2013) }\end{array}$ & Guangzhou, China & $\begin{array}{c}\text { Macro Urban } \\
\text { Community Study }\end{array}$ & socio-spatial & $\begin{array}{c}\text { Housing } \\
\text { Socio-economic status } \\
\text { Demography } \\
\text { Management }\end{array}$ & Enclave Urbanism \\
\hline
\end{tabular}

Drawing on the literature in Table 1, and in agreement with growing body of work on the socio-spatial aspects of old Chinese cities, we derive a framework (Figure 1) that posits that changes in urban neighbourhoods result from major policy or regulatory interventions at the national level in China [15,18], specifically the Urban Housing Reform and the Reform and Opening Up. Following the existing literature, spatial changes are considered from the physical and morphology aspect of the built environment such as building condition, street and public space accessibility and housing facility. On the other hand, social condition encompass phenomena and modifications in the human sphere, such as residents activities, housing tenure and social solidarity. While we identify spatial and social changes separately in our framework, we concur with Gür and Enön [20] that social and spatial changes do not occur independently but rather as interdependent process that constantly intersect and also respond to various policies and factors at global, national and local levels.

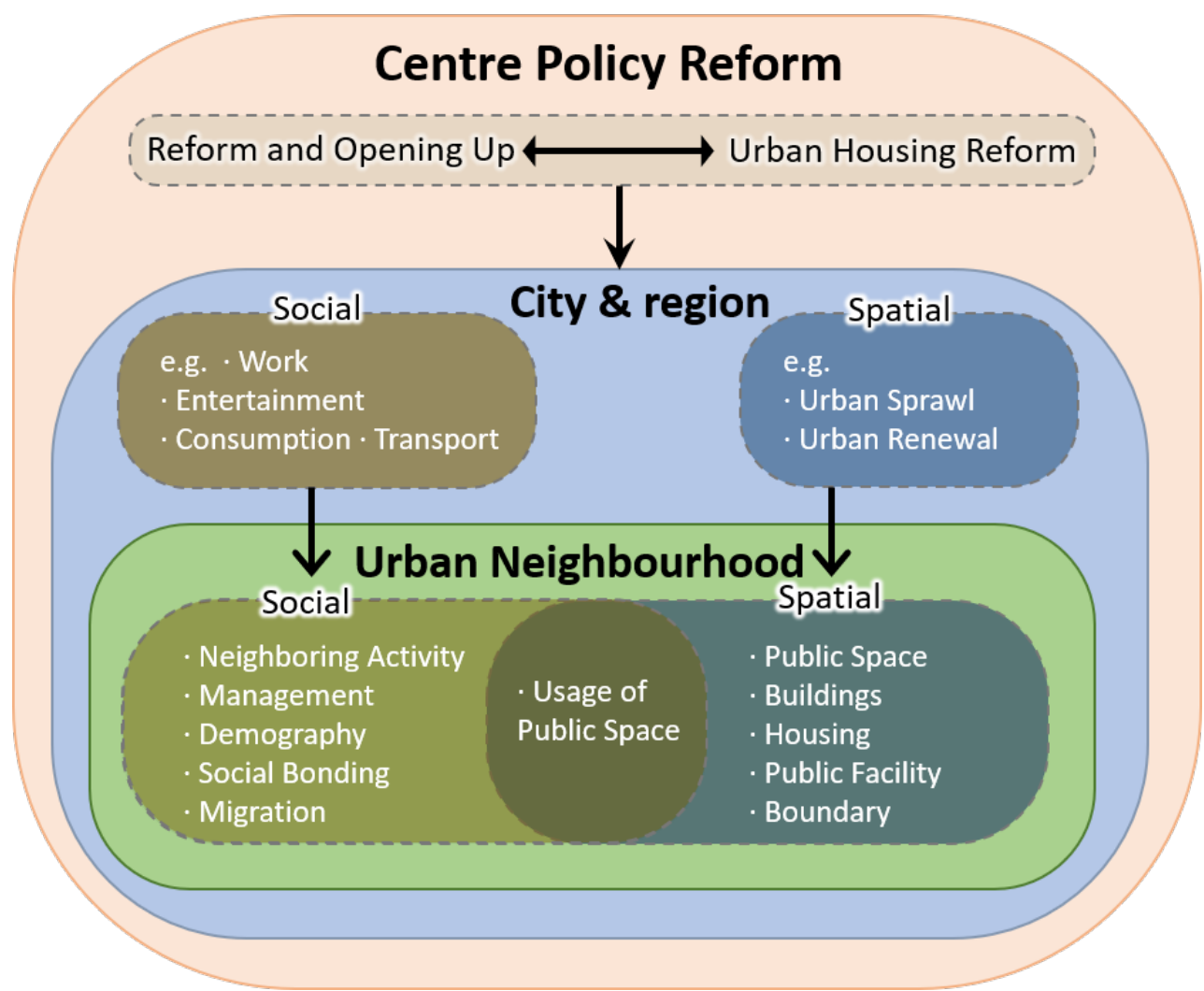

Figure 1. Frame of socio-spatial changes: elements and impact transmission at different levels.

In summary, this socio-spatial changes framework provide certain specificity that help to properly understand dynamics of urban neighbourhood transformation. Based on this, our study argues that in the case of cities experiencing rapid urban transformations, such socio-spatial changes help unravel the specific details of evolution of urban neighbourhoods and to respond in a manner that capture the dynamics especially against socio-spatial discontinuities. 


\section{Materials and Methods}

\subsection{Overview of Hefei City and the AMS Danwei Compound}

Hefei city is the capital of Anhui Province. It located in the middle and lower reaches of the Yangtze River plain with flat terrain in its built-up area [25]. Anhui Province is located in the eastern part of China, borders JiangSu province to the east, ZheJiang and Jiangxi province to the south, HuBei, HeNan, and Shandong to the west and north. While the city of Hefei locates in the middle of Anhui province, about $400 \mathrm{~km}$ to the west of the city of Shanghai (Figure 2). As of 2019, Hefei had a total area of 11,445.1 square kilometres, a resident population of $8,189,000$ and an urbanisation rate of $76.33 \%$ [26].

Hefei city has a history of over 2000 years. According to the Hefei Local Gazetteers [27], the population peaked before the foundation of the PRC (1949) was around 1,600,000 in the year 1820. Afterwards, the population dropped rapidly due to various wars and the overall recession of China. World War II and other civil wars particularly damaged the urban built-up areas and led to a decline in population to 69,015 residents in 1949 [27]. Following the founding of the People's Republic of China, and especially after the city was designated as the capital of Anhui province in 1952, Hefei city has experienced a rapid development. The population has increased from 69,015 in 1949 to 7.96 million in 2018 [28]. In the early years of the PRC, the development of Hefei was concentrated in the old town and surrounding areas [27]. The old town area mainly concentrates Danweis with functions such as government institutions, public services and commerce. Industrial production, universities, and other large-scale, resource-intensive, polluting Danweis were geographically situated outside the old town.

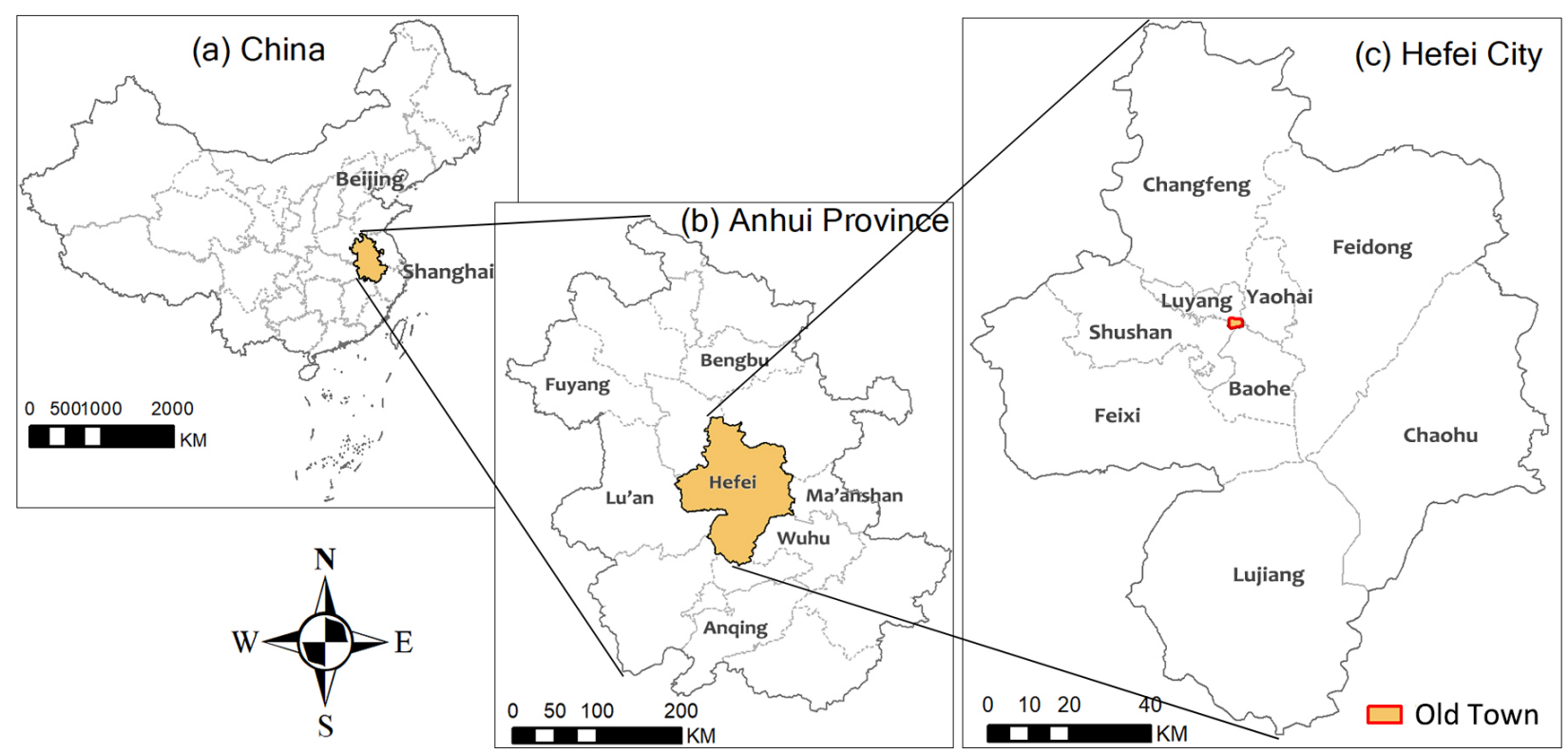

Figure 2. Location of Hefei City and its Old Town (data source: mapbox.com (accessed on 30 March 2021)).

This paper highlights the case of one Danwei compound in Hefei city, the AMS Danwei compound. It is located in the southwest part of the Old Town Area of Hefei city (Figure 3). This compound has an area of about 34,500 square meters (in 2018) and around 900 residents. It has a university to the east, a high school to the north and a large water body to the south and west. As shown in Figure 3, the area is also not far from everyday facilities such as shopping streets. This compound contains several Danweis in the public health system. The leading Danwei in this compound was the Centre for Disease Control and Prevention (CDC) of Anhui Province before 1980. At present, the biggest Danwei in the compound is the Anhui Academy of Medical Science, subsequently referred to as the AMS compound in this paper. For convenience, all Danweis in the current AMS compound 
will be referred to in this paper as AMS Danweis. To present a pictorial perception of the study area, Figure 4 provides photographs of the public spaces of the AMS compound.
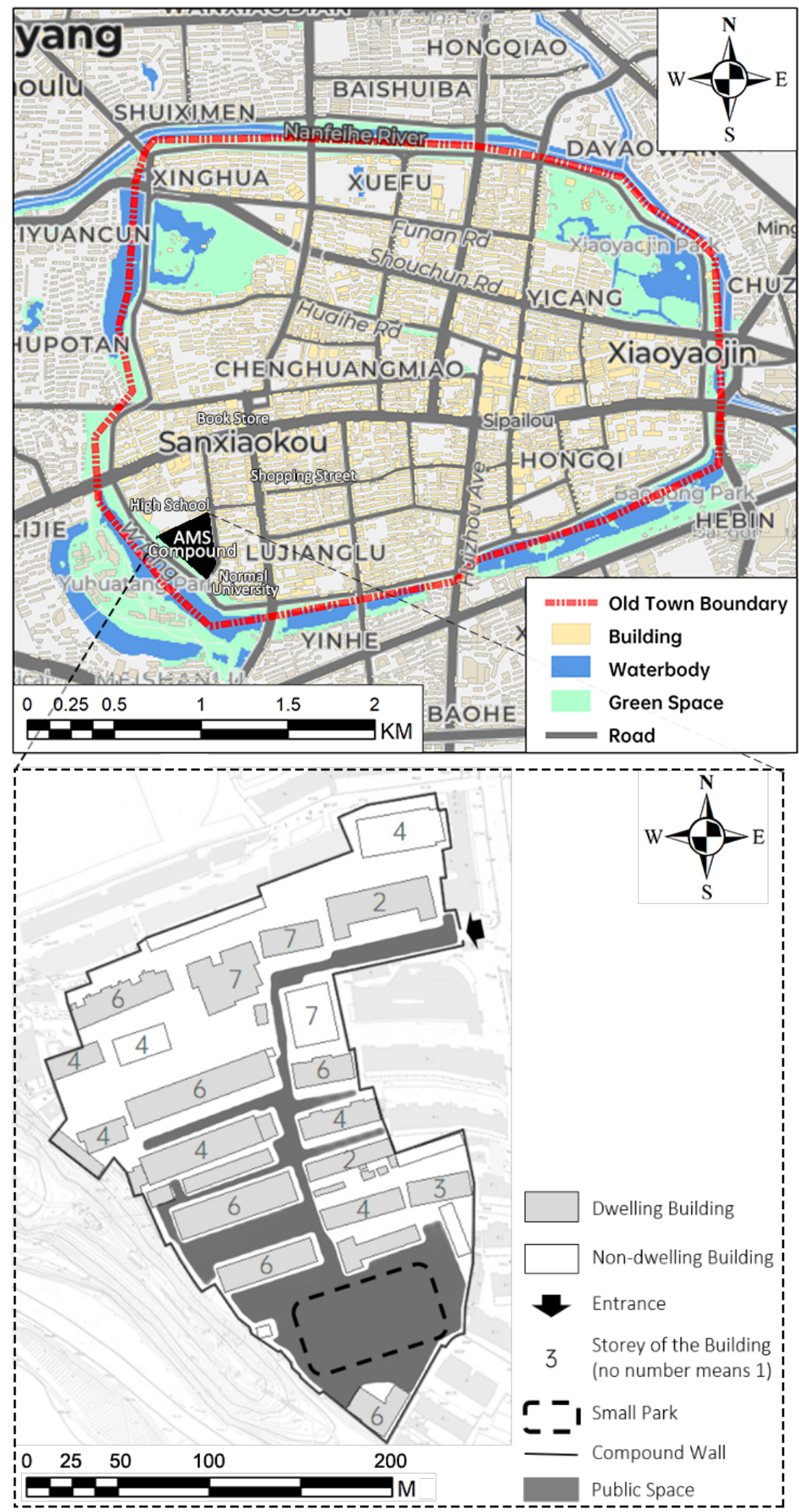

Figure 3. Map of Hefei Old Town and the AMS Danwei compound. 


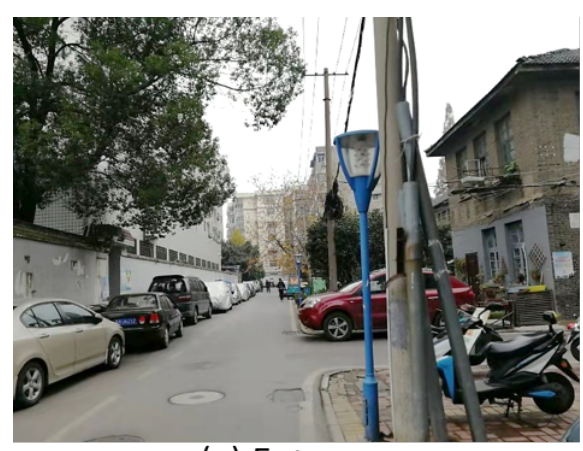

(a) Entrance

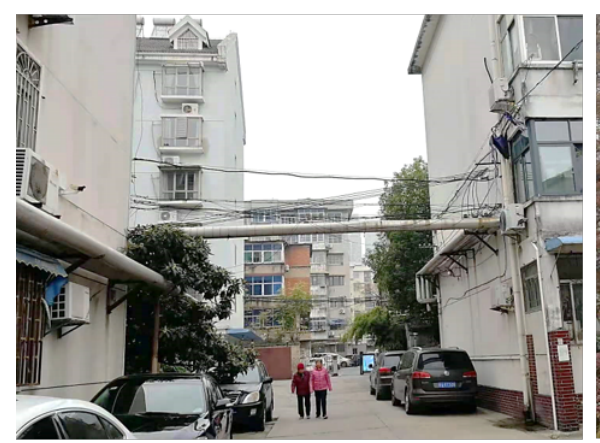

(d) Internal Path

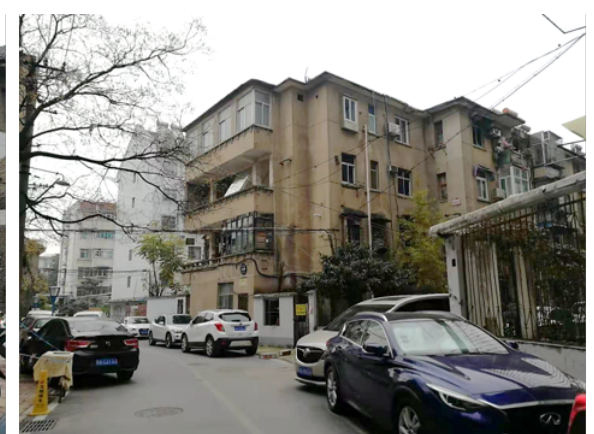

(b) Internal Path

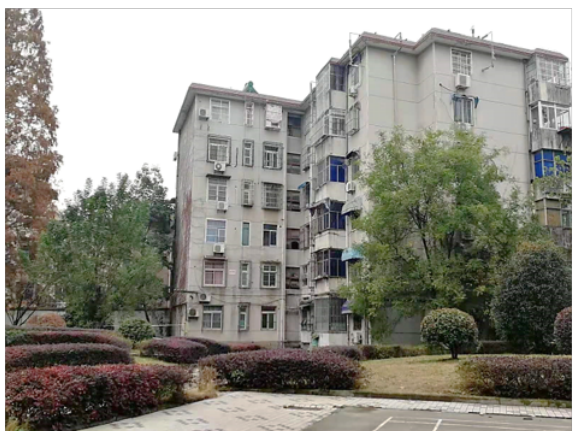

(e) Internal Park

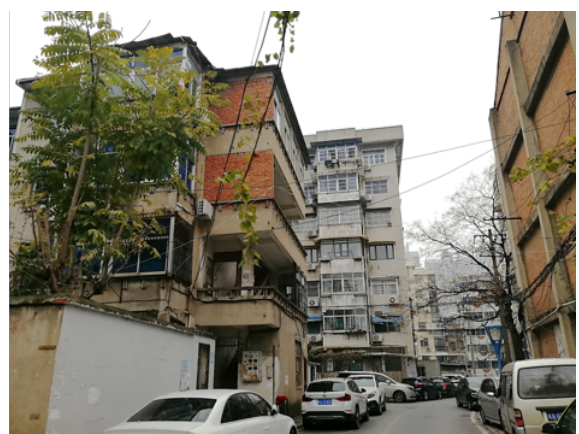

(c) Internal Path

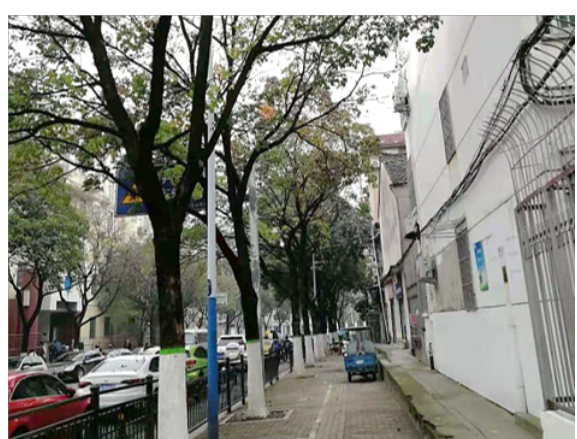

(f) External Sidewalk

Figure 4. Photos of the AMS compound.

\subsection{Methodology}

This paper focuses on the AMS Danwei compound to analyse socio-spatial changes before and after the two reforms. It addresses the research questions of: what are specific social and spatial changes in Danwei compound after the reforms. For this research question, this paper employed both qualitative and quantitative content analysis. As shown in Figure 5, a multi-method data collection approach was used to study the socio-spatial features of the AMS Danwei compound both before and after the reforms, for a comparison in a time domain. In this framework, (a) the changes in physical space, including public space and buildings, and (b) the management of the AMS compound, then (c) the changes in the residents' use of public space were described. Subsequently, combining the above results with the relevant literature, we tried to discuss the causes, mechanisms and impacts that produce the above changes. Finally, we discuss the planning and design measures that should be adopted in the transition period of such Danwei compounds.

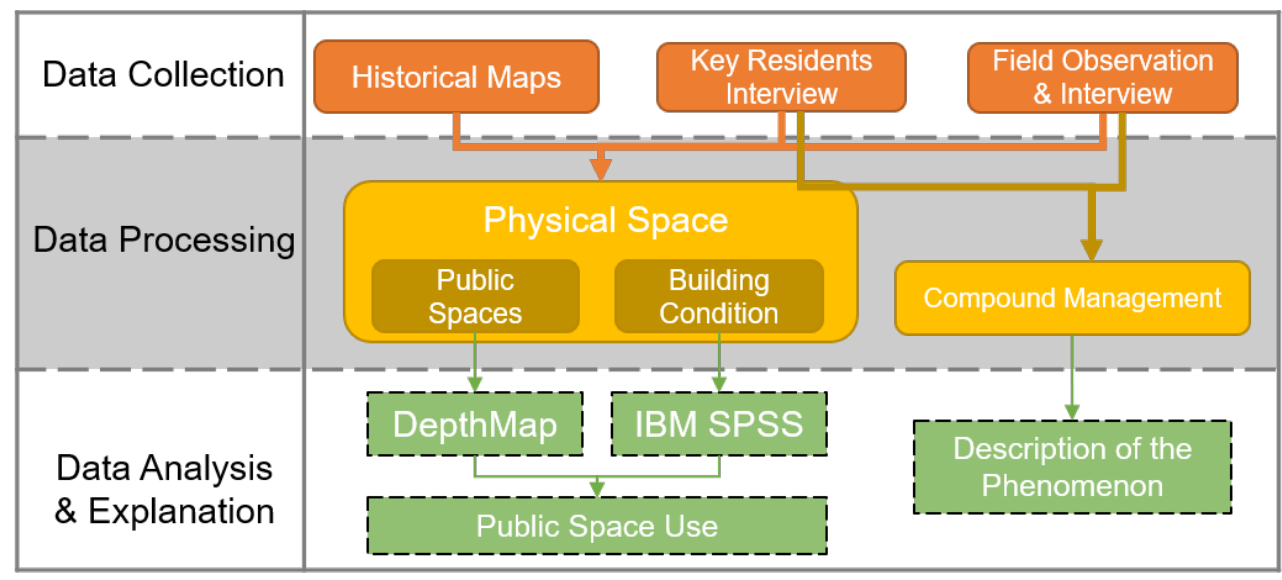

Figure 5. Study's workflow. 


\subsubsection{Data Collection}

In order to achieve comparisons in a time domain, two main time frames were selected. The sampling time points for social related data were set for 'before the reforms' (before 1997) and 'after the reforms' (current situation). The reasons for using this time sampling is (i) the reforms lasted over a long period of time and it was until the Urban Housing reforms of 1997 that the effects became clear; and (ii) and the reliance on interviews for lack of objective data such as historical records. We therefore have to rely on key person interviews for past information, and it is difficult for individual memory to recall the conditions of the social context clearly. For pure spatial data, the sampling time points were set for 1961, 1975, 1987, 1999 and 2018 due to the availability of maps for these years. The data of 1961, 1975, 1987 are considered to be 'before the reforms', while 1999 and 2018 are considered to be 'after the reforms'.

In this study, socio-spatial changes are analysed from the perspective of both physical space changes and social life changes. Limited by publicly accessible data, four elements were selected. Buildings and public spaces were selected as spatial study aspects. In terms of social elements, management of the compound and the usage of public space were selected. Different data collection methods were used for different research aspects in different time periods (Table 2). The methods involved are described below.

Table 2. Data collection methods for different research aspects.

\begin{tabular}{ccc}
\hline Socio-Spatial Elements & Before the Reforms & After the Reforms \\
\hline Public Spaces & KP, MA & MA, FO \\
Building Features & KP, MA & MA, FO \\
Usage of Public Spaces & KP, MA & MA, FO \\
Compound Management & KP & FO \\
\hline
\end{tabular}

MA: Mapping. KR: Key Residents Interview. FO: Field Observation.

Mapping: The original paper maps were sourced from the Hefei City Bureau of Geomatics gallery. The surveying and mapping years were obtained for 1961, 1975, 1987 and 1999. These maps are at a scale of 1:500 and show the enclosure walls, the outlines of the buildings, the building storeys and the building materials. The authors redrew these maps in AutoCAD. The map of 2018 was drawn based on field research, satellite photos and the 1999 map. All the digital maps were imported into ArcGIS and DepthMap software for further analysis.

Key Residents Interview: The main informants were selected through a snow ball method. The first author contacted a retired employee (informant I) of the AMS Danwei compound who provided a list of six potential respondents for further interviews based on the criteria of the person being a long term resident of the AMS compound and very familiar with social and spatial aspects of the neighbourhood. After initial contacts, three of the six listed persons were available for interviews. Our final four key informants selected all have lived in the AMS Danwei compound for over 50 years, including a retired employee of one Danwei in the compound (informant I), a university professor (informant II), a government specially honoured architect (informant III) and a retired middle-level manager of one Danwei in the compound (informant IV). In all of the interviews with informants, the key persons were first shown maps of the compound from 1961, 1975, 1987 and 1999 obtained from the Hefei City Bureau of Geomatics and asked to recall and describe the areas based on the maps. Additionally, informants were asked to indicate on the map the location of social activities before the reforms. Generally, the interviews covered both social and spatial aspects such as building functions, public space usage, maintenance of public facilities and residents social life. The interviews were conducted face-to-face and lasted about one and a half hours on average. All interviews were conducted by the first author in Chinese and transcribed in English.

Given the historical nature of the informant interviews, we applied the descriptive validation to improve the credibility and validity of the responses $[29,30]$. That is, all interviews were reviewed with a retired Danwei director (validator I), highly recognised an 
expert of the AMS Danwei compound. Any suggested in consistences in the responses were reported back to informants to clarify narratives and address any issues lapses in recollecting old events. Although such informal interviews on historical events can be subjective or constrained by romanticising of the past, studies show that they enrich the diversity of data sources and accord long-term residents as relevant sources of knowledge [31-33].

Field Observation: During May to August, 2018, observations of socially relevant activities and building/space features were conducted in the AMS compound. Transect walk method was chosen and implemented by the first author across the compound to observe the buildings, streets, public spaces and residents' activities. The observations were sometimes combined with incidental conversation with the garbage collectors, compound cleaners, public facility users, and commuters to and from work, which provided additional information about compound management and residents' attitude toward current AMS compound.

\subsubsection{Data Processing and Analysis}

The physical space of the AMS compound was mapped in the digital maps and marked by the information provided by Key Residents Interview and Field Observation. From the digital maps, basic information about the boundaries and the area of the compound could be easily obtained. Following this, the study highlighted the public space. The concept of 'Public Space' in this paper includes common spaces, transportation spaces, greening, and some other open spaces in the AMS compound. The public space of the AMS compound was mapped in the digital maps. From the digital maps, it was easy to obtain basic information about the compound outline, area and other data.

For the further analysis of the public space, spatial syntax analysis was applied using DepthmapX software. As a method of quantitative spatial analysis, space syntax is able to highly relevant insights in the analysis of both long-term changes in urban space [34] and public space [35,36]. The Visibility Graph Analysis approach in DepthmapX was chosen for the neighbourhood-scale public space analysis. A grid of $1 \times 1 \mathrm{~m}$ covering the whole compound was made as the basic analysis units. From the analysis result, three kinds of frequently used indicators were selected, including Visual Step Depth, which measures the visible depth of the cell from the entrance; Connectivity, which calculates the strength of the connection between all cells in the internal space; and Scatter Plot of different years, composed of Connectivity value and Metric Step Shortest-Path Length (a kind of Spatial Depth value, showing the length of the shortest path from the entrance to the cell), reflects the general character of the public space.

For the analysis of building features, the number of storeys, materials and functions of each building in each period was annotated in ArcGIS, based on the information provided by Key Residents Interview and Field Observation. Then, the area calculation function in ArcGIS was used to obtain the footprint area of each building, which allows for further calculations, such as floor area and compound plot ratio. The attribute tables in ArcGIS were then exported to IBM SPSS for descriptive statistics of the building related changes.

In the analysis of the management of the compound, an attempt was made to locate the key actors, including initiators, funders, and participants. The Key Residents Interview as well as the Field Observation provided information on the pre/post-reforms periods, respectively.

In addition to the above analysis, we also tried to reconstruct some of the patterns of residents' use of public space before and after the reforms, based on information obtained from the Key Residents Interview, mapping and Field Observation.

\section{Results}

\subsection{Physical Space Changes}

\subsubsection{Boundary and Density}

Figure 6 shows the changes in the physical boundary (1961-2018) of the AMS. The result show two significant boundary changes in the history of the AMS compound. 

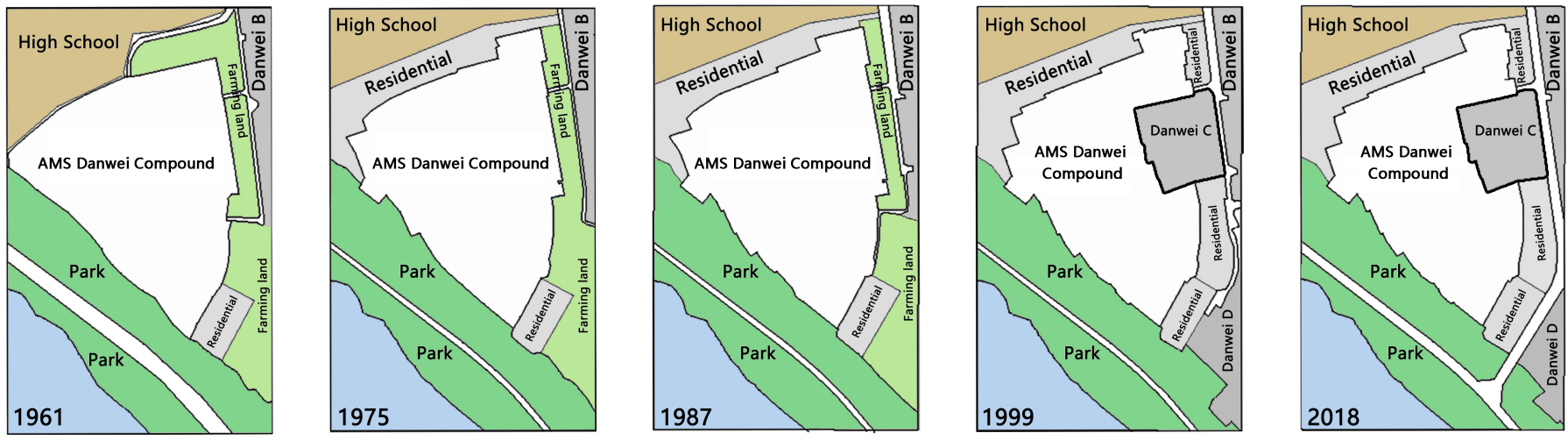

Figure 6. Boundary of the AMS Danwei compound and surrounding land usage.

Table 3 shows the basic indicators of building density and plot ratio in the AMS compound. Building density increased steadily till 1999 and remained stable since; the plot ratio had increased rapidly from 1961 to 2018. The compound had been getting denser.

Table 3. Building density and plot ratio of AMS compound.

\begin{tabular}{cccccc}
\hline & $\mathbf{1 9 6 1}$ & $\mathbf{1 9 7 5}$ & $\mathbf{1 9 8 7}$ & $\mathbf{1 9 9 9}$ & $\mathbf{2 0 1 8}$ \\
\hline Building Density & $20 \%$ & $27 \%$ & $42 \%$ & $48 \%$ & $48 \%$ \\
Plot Ratio & $32 \%$ & $47 \%$ & $77 \%$ & $149 \%$ & $151 \%$ \\
\hline
\end{tabular}

\subsubsection{Public Space}

Based on the digital maps, the public spaces in each period were drawn (Figure 7) with their areas and occupancy calculated (Table 4). It could be seen from Figure 7 that the public space in the AMS compound gradually declined, from a block form in 1961 and 1975 to a net form in 1987. After the 1997 reform, it shrank further into a tree-like spatial structure. In specific numbers, the area and ratio of public space declined rapidly, most notably between 1975 and 1999, from 25,870 square metres (65\%) in 1975 to 9690 square metres (28\%) in 1999. During the same period, the building density rose rapidly from $27 \%$ to $48 \%$, and the plot ratio more than tripled from $47 \%$ to $149 \%$. From the above data, it can be seen that the public spatial system of the AMS Danwei compound before and after the reforms has drastically altered. According to the key residents and field observation, the decline in public space after the reviews was due to the increase in residential housing promoted by the urban housing reforms and the growing car ownership without accompanying parking.

Table 4. Basic spatial information of AMS compound.

\begin{tabular}{cccccc}
\hline & $\mathbf{1 9 6 1}$ & $\mathbf{1 9 7 5}$ & $\mathbf{1 9 8 7}$ & $\mathbf{1 9 9 9}$ & $\mathbf{2 0 1 8}$ \\
\hline Public Space Area $\left(\mathrm{m}^{2}\right)$ & 29,740 & 25,870 & 17,060 & 9690 & 8200 \\
Public Space Ratio & $75 \%$ & $65 \%$ & $42 \%$ & $28 \%$ & $24 \%$ \\
\hline
\end{tabular}




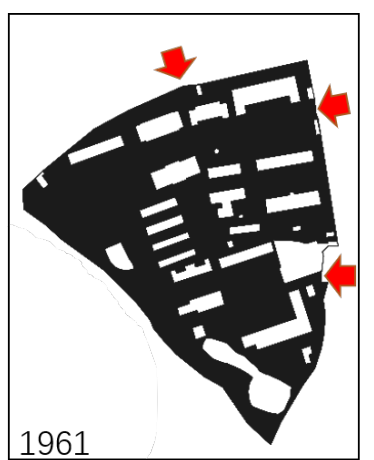

1975
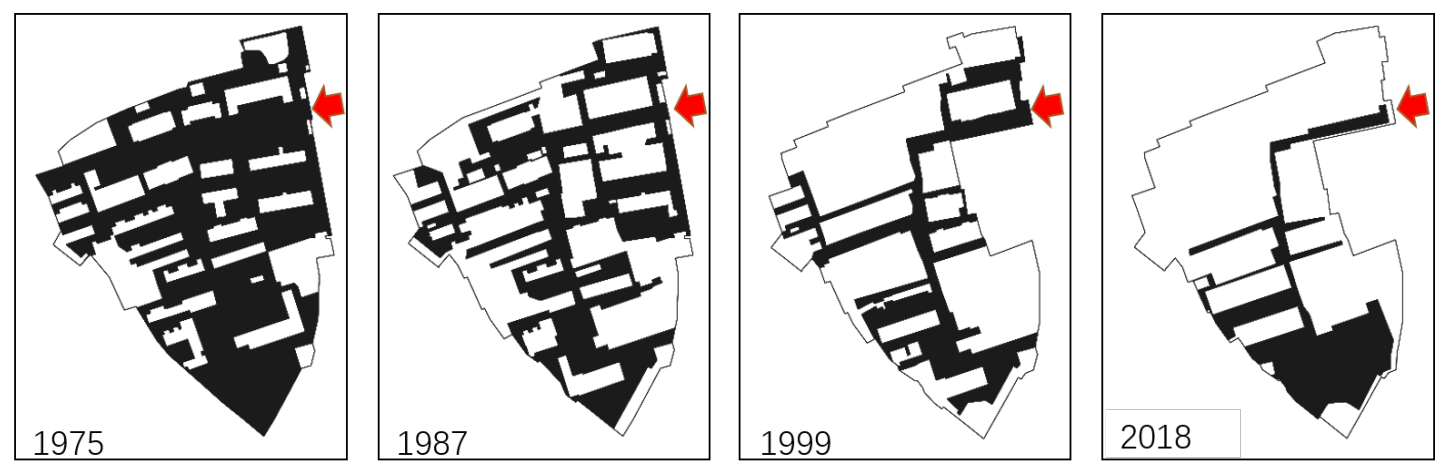

Figure 7. Public space map of the AMS compound (1961-2018).

\subsubsection{Spatial Syntax Analysis}

DepthMapX software was used for a spatial syntax analysis on the public spaces. The value obtained from the Visual Step Depth analysis stands for the turns needed to walk from the entrance to that point. As evident in Figure 8, the proportion of area with high visual spatial depth kept increasing since 1961. In 1961, with two turns from the entrance, $99 \%$ of the public places in the compound could be seen. Such accessible space decreased significantly to $49 \%$ in $1975,42 \%$ in $1987,27 \%$ in 1999 and $12 \%$ in 2018 . Field observations revealed compound had becoming increasingly difficult for outsiders to walk through.
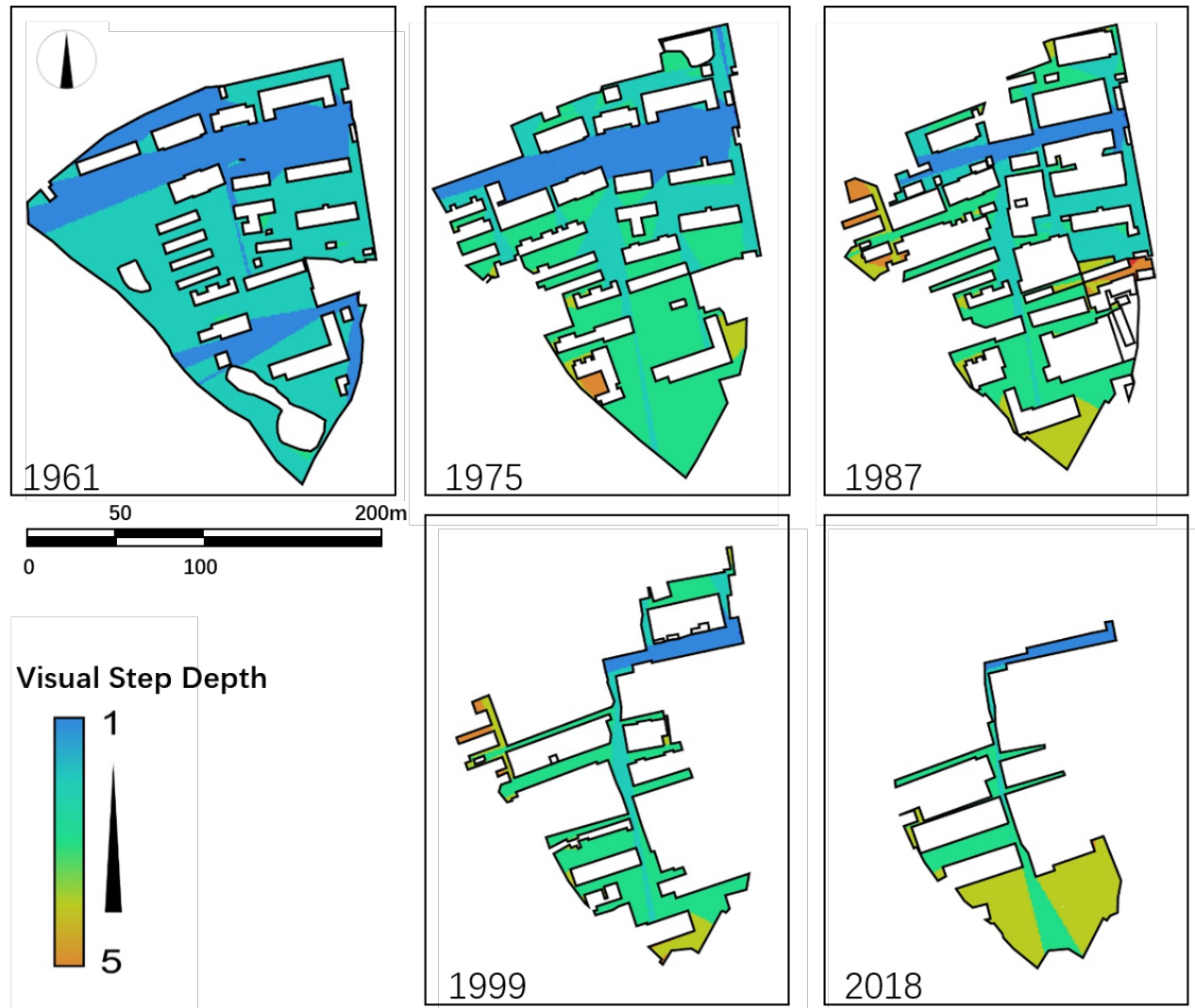

Figure 8. Visual step depth of the AMS compound (1961-2018).

Connectivity values refer to the strength of the connection between the cell and all other cells in the public space (Figure 9). In a residential environment, a place with a higher connectivity value has better potential as a social or common space. From 1961 to 1999 , the analysis showed that the overall connectivity in the AMS compound decreased significantly. In 2018, the connectivity remained poor, except for the new emerged common space (a neighbourhood park) in the south end. 


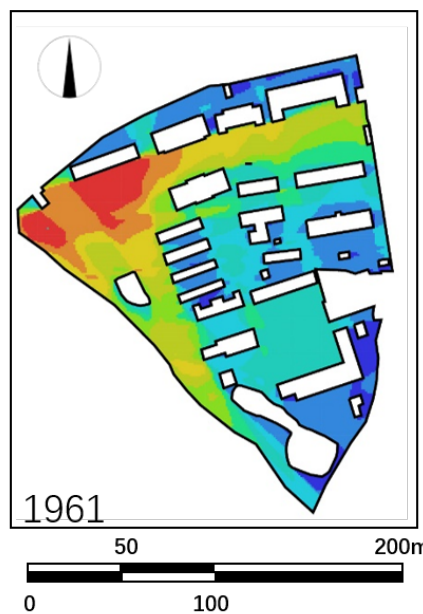

\section{Connectivitv}

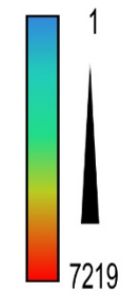

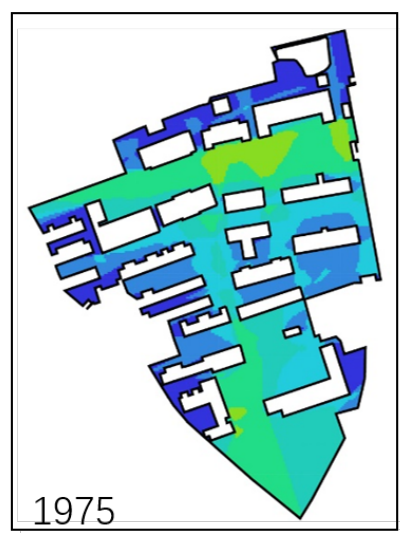

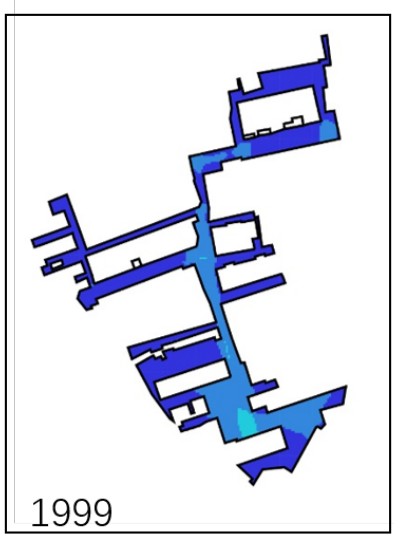

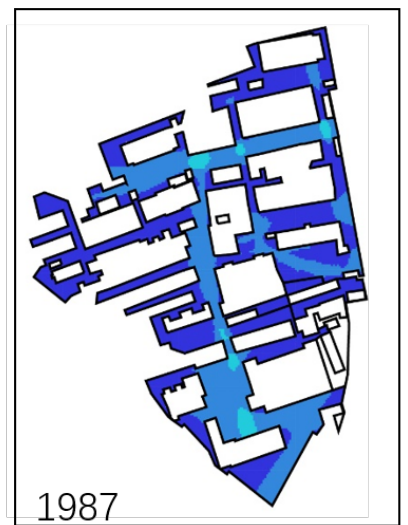

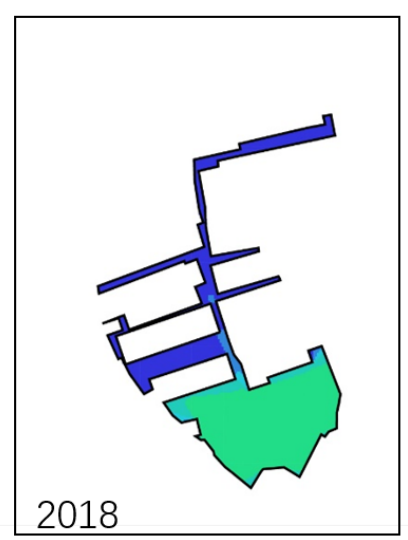

Figure 9. Connectivity of the AMS compound (1961-2018).

By the scatter plot with the $x$-axis represents the Connectivity value, and the $y$-axis represents the Metric Step Shortest-Path Length, Figure 10 presents a relatively visual representation of the public space spatial characteristics of different years. Each point in the scatter plot stand to one $1 \times 1 \mathrm{~m}$ cell in the compound. In the earlier years (1961 and 1975), the cells tend to have higher connectivity and low Metric Step Shortest-Path Length. Meanwhile, the points laid in an organic pattern, suggesting that there were large public spaces existing with a regular patch shape. After the 1997 reform, in 1999 and 2018, the points tend to have deficient connectivity and much higher Metric Step Shortest-Path Length, with the points forming a linear pattern, suggesting there were few public spaces, albeit narrow and linear. In general, over the years, public space had degenerated from an organic, blocky, low depth pattern to a linear, striped, large depth pattern.

In summary, the data of 1961, 1975 and 1987 shows that the public space in the AMS compound had been shrinking before the reforms, but maintained a reticulated spatial form with relatively moderate spatial depth and connectivity. The data from 1999 and 2018 shows that, after the reforms, the public space in the AMS compound shrank into a tree-like structure and experienced issues such as excessive spatial depth and low internal connectivity. These results suggest that after the reforms, the public space in the AMS compound had largely lost its function as a space for public activities and was only capable of basic transportation. 


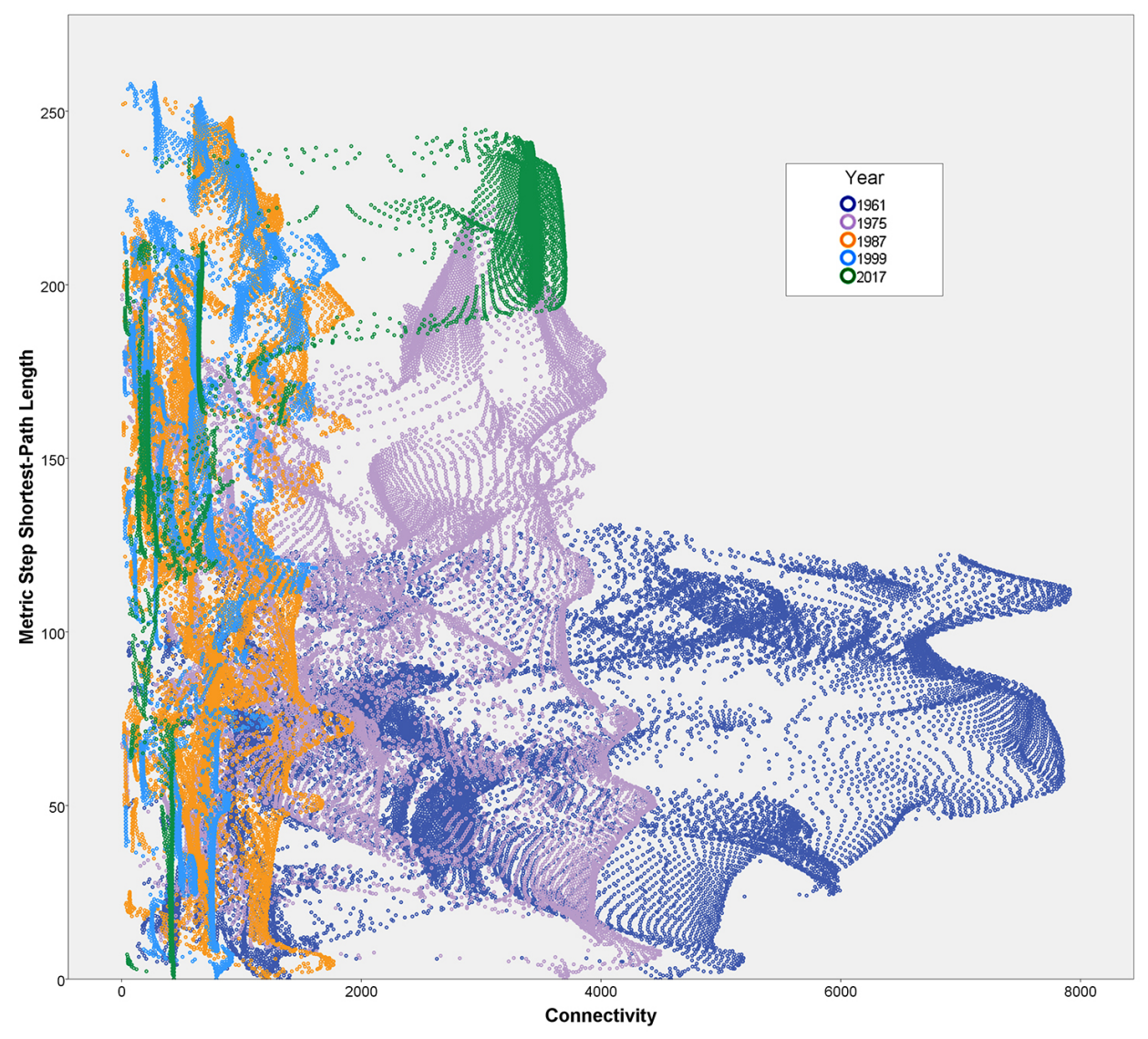

Figure 10. Scatter plot by connectivity and spatial depth of the AMS compound.

\subsection{Building Features}

As shown in Table 5, before the reforms, the total floor area and average building area increased significantly. Before the 1997 reform, the total area of buildings in the compound grew from 12,699 square metres in 1961 to 31,032 square metres in 1987. Around the time of the 1997 reform, the floor area in the compound grew rapidly, reaching 51,386 square metres in 1999. After the reforms, the floor area within the AMS compound has remained largely unchanged, at 51,862 square metres in 2018. The AMS compound has also been experiencing a consistently high building renewal rate. In particular, in 1999, new construction accounted for more than half of all floor space. According to the residents, the high building renewal rate was premised on improvements of indoor living and working environment, thereby increasing interior floor area and overall building quality. The quantity of buildings within the compound has remained roughly the same (39 in 1961 and 36 in 2018), while the size of the individual buildings has continued to increase (326 square metres in 1961 and 2096 in 2018). Note that the change in 1987 and 1999 was because of the construction of a large number of temporary earthquake resistant shelter.

In the AMS Danwei compound, the field survey and key residents interview revealed nine main functions (Figure 11, Table 6). Building functions include: Mix-use buildings which usually have office-residential-warehouse functions, with the residential unit as the biggest part, (exist due to the lack of sufficient buildings to accommodate the different functional requirements); Animal House refers to the building that breeds public health experimental animals; and Earthquake Resilient Shelter refers to the temporary residential shelters which appeared after the Tangshan earthquake. 
Table 5. Building area and quantity in the AMS compound (1961-2018).

\begin{tabular}{cccccc}
\hline & $\mathbf{1 9 6 1}$ & $\mathbf{1 9 7 5}$ & $\mathbf{1 9 8 7}$ & $\mathbf{1 9 9 9}$ & $\mathbf{2 0 1 8}$ \\
\hline Total Building Area $\left(\mathbf{m}^{2}\right)$ & 12,699 & 18,543 & 31,032 & 51,386 & 51,862 \\
\hline In Which: Retention Area $\left(\mathrm{m}^{2}\right)$ & & 11,001 & 17,736 & 23,054 & 39,287 \\
In Which: New Build Area $\left(\mathrm{m}^{2}\right)$ & & 6180 & 13,973 & 26,626 & 12,574 \\
\hline Average New Building Area $\left(\mathrm{m}^{2}\right)$ & 326 & 247 & 318 & 634 & 2096 \\
\hline New Build/Total Area Ratio & & $33 \%$ & $45 \%$ & $52 \%$ & $24 \%$ \\
\hline Total Quantity & 39 & 41 & 75 & 78 & 36 \\
\hline In Which: Retention Quantity & & 16 & 31 & 36 & 30 \\
In Which: New Build Quantity & & 25 & 44 & 42 & 6 \\
\hline
\end{tabular}
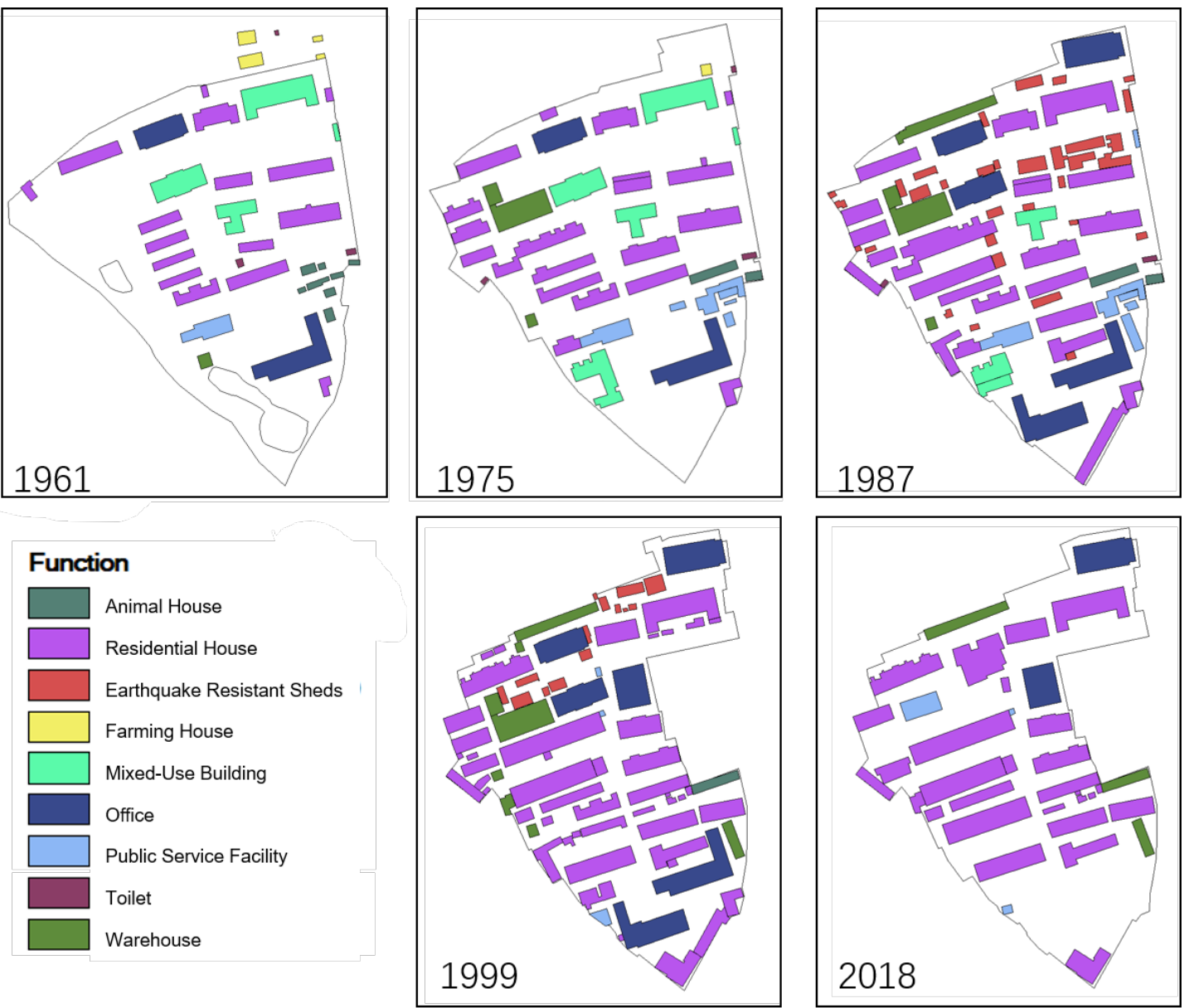

Figure 11. Building function map of the AMS compound.

Most of the buildings in the AMS compound were offices and residential houses, with other buildings of supporting functions. Before the reform, offices and residential houses in the compound had been growing rapidly. Along with the continuous construction of new buildings, mixed-use buildings were rapidly decreasing. For example, in 1961 (before the reforms), the predominant building functions were office (19\%), residential house (44\%), mixed-use building (28\%), with a small number of warehouses $(1 \%)$, public services $(3 \%)$, farming houses (2\%) and animal houses (2\%). With the construction and the renewal of the buildings, in 1987, the predominant building functions were only offices (32\%) and residential houses (49\%), while other functions decreased, except for the addition of a new function of Earthquake Resilient Shelter (7\%). These earthquake resilient shelters were built 
by the residents themselves for the possibility of a major earthquake. The AMS compound of this period was a typical mixed function work-residential neighbourhood.

Table 6. Building area and proportion by function.

\begin{tabular}{|c|c|c|c|c|c|c|c|c|c|c|}
\hline \multirow{2}{*}{$\begin{array}{c}\text { Building Area by Function }\left(\mathrm{m}^{2} \mid \%\right) \\
\text { Office }\end{array}$} & \multicolumn{2}{|c|}{1961} & \multicolumn{2}{|c|}{1975} & \multicolumn{2}{|c|}{1987} & \multicolumn{2}{|c|}{1999} & \multicolumn{2}{|c|}{2018} \\
\hline & 2388 & $19 \%$ & 3250 & $18 \%$ & 10,086 & $32 \%$ & 14,118 & $27 \%$ & 6940 & $13 \%$ \\
\hline Residential House & 5643 & $44 \%$ & 8565 & $46 \%$ & 15,323 & $49 \%$ & 34,605 & $67 \%$ & 42,782 & $82 \%$ \\
\hline Mixed-Use Building & 3598 & $28 \%$ & 4670 & $25 \%$ & 997 & $3 \%$ & 0 & $0 \%$ & 0 & $0 \%$ \\
\hline Warehouse & 79 & $1 \%$ & 841 & $5 \%$ & 1308 & $4 \%$ & 1558 & $3 \%$ & 752 & $1 \%$ \\
\hline Public Service Facility & 346 & $3 \%$ & 848 & $5 \%$ & 961 & $3 \%$ & 129 & $0 \%$ & 1387 & $3 \%$ \\
\hline Farming House & 277 & $2 \%$ & 51 & $0 \%$ & 0 & $0 \%$ & 0 & $0 \%$ & 0 & $0 \%$ \\
\hline Toilet & 57 & $0 \%$ & 47 & $0 \%$ & 51 & $0 \%$ & 0 & $0 \%$ & 0 & $0 \%$ \\
\hline Animal House & 311 & $2 \%$ & 270 & $1 \%$ & 270 & $1 \%$ & 203 & $0 \%$ & 0 & $0 \%$ \\
\hline Earthquake Resilient Shelter & 0 & 0 & 0 & 0 & 2051 & $7 \%$ & 789 & $2 \%$ & 0 & 0 \\
\hline
\end{tabular}

After the reforms, the building functions saw considerable changes. Specifically, residential house had become the dominant building function, increasing to $67 \%$ in 1999 and $82 \%$ in 2018. The change in floor area by functions shows a rapid decline in office and ancillary functions such as warehouse. The reformed AMS compound reflects a strong tendency towards pure residentialisation. This period has also seen a regrowth in public service buildings. In 1999, the area of public service facilities had fallen to only 129 square metres; by 2018, it had rebounded to 1387 square metres, or 3\% of all buildings, due to the rising demand for elderly care.

\subsection{The Use of Public Spaces and Public Facilities}

The Danwei compound had been a common living space, where public facilities, such as water supply and toilet, have a direct influence on daily life. Before the reforms, such facilities were communal as they were not available within existing residential housing units in the AMS compound. For example, tap water was built near residential buildings as a shared facility by several households residing in surrounding buildings (Figure 12). Similarly, there were three public toilets that were communally used by all households within the compound. Without drainage facilities, waste water was indiscriminately disposed into surrounding vegetation. According to interviews, communal and shared use of facilities created strong social bonds among residents. Long-time residents disclosed that several social groups were formed around shared facility usage (e.g., shared tap water) as neighbours would often socialise on a daily basis through interactions and conversations about the facilities, conditions and maintenance.

However, this socialisation around shared use began to change in the late 1970s, following the construction of the first apartment building with indoor tap water and toilets in the compound. Specifically, in the late 1980s, the city government embarked on housing renovation in the Danwei compounds with particular emphasis on the installation of housing facilities such as tap water and toilet within each housing unit. By the early 1990s, the water supply and drainage system had been completely interiorised in the AMS compound. Consequently, the residents' shared use of public utilities and corresponding social interactions and communalisation that came with them gradually disappeared (Figure 13). 

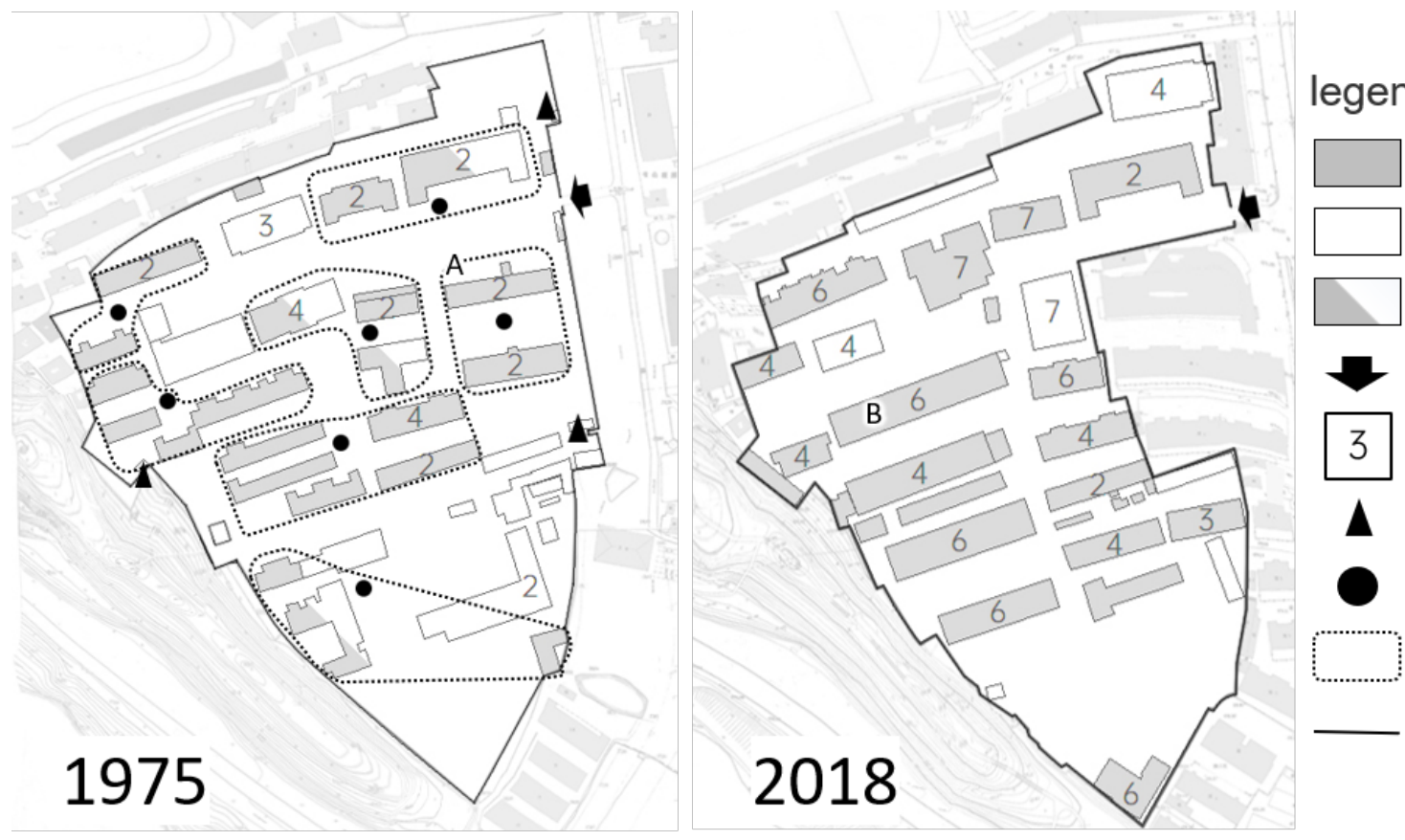

legend

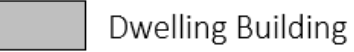

Non-dwelling Building

Mix-use Building

Entrance

Storey of the Building

(no number means 1)

Public Toilet

Public Tap Water

Social Group

Compound Wall

Figure 12. Public water supply, toilets and buildings of the AMS Danwei compound.

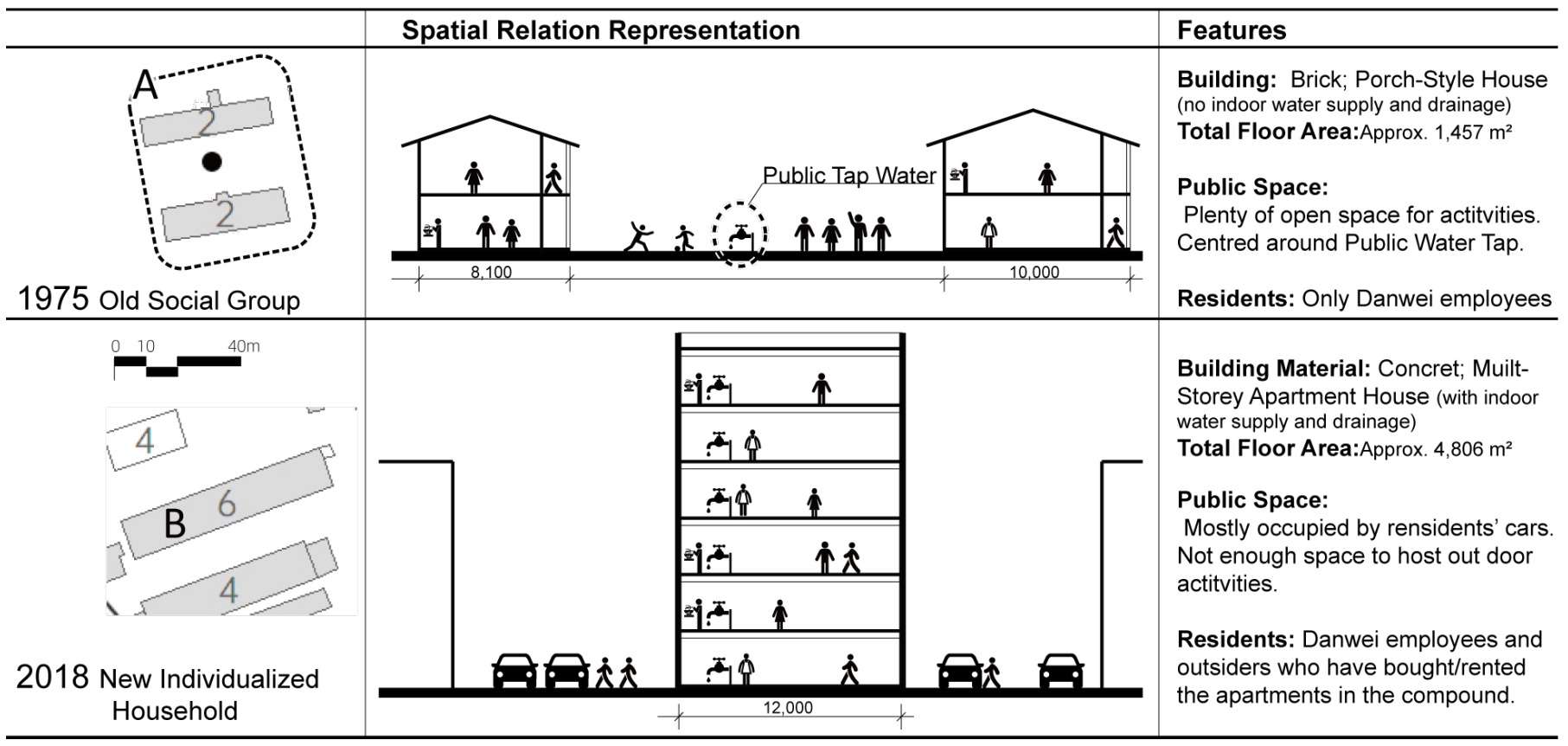

Figure 13. Living environment conditions. (A, B represent the building and public space marked by A, B in Figure 12).

\subsection{Compound Management}

This part of the study analyses the actors for the management and maintenance of public facilities in the AMS Danwei compound. As earlier mentioned, most facilities were commonly shared before the reforms and thus the responsibility of the AMS Danweis to manage and maintain. After the reforms, the changes in compound management emerged as a result of the changes in communalisation. Interview with key persons indicated that there were three main aspects of management and maintenance, including (i) the origin of a proposed idea or action, (ii) the source of funding and (iii) the workers or person responsible for executing the maintenance action. Further, four public services or facilities were identified as the basis for analysing. These are garbage collection, compound cleaning, 
facility / equipment maintenance (e.g., street light and water pipe maintenance), and human excreta disposal. These public services or facilities are selected because they were the most common resident-related. The results (Table 7) indicate that, before the reforms, the AMS Danweis held the responsibility for the maintenance of the compound since they owned the land and properties within the compound. More so, the Danwei employed professional electricians, plumbers and cleaners to undertake necessary facility repairs and maintenance. These professionals (shown as 'Employee' in Table 7) were full-time employees who lived in the compound. During this period, general residents were more actively engaged in daily maintenance activities such as compound and building cleaning.

Table 7. Main actors in the compound maintenance.

\begin{tabular}{|c|c|c|c|}
\hline \multirow{2}{*}{ Maintenance Activities } & \multirow{2}{*}{ Actors } & \multicolumn{2}{|c|}{ Period } \\
\hline & & Before the Reforms & After the Reforms \\
\hline \multirow{3}{*}{ Garbage Collection } & Initiators & Government & Government \\
\hline & Funding & Danwei & Government \\
\hline & Participants & Employee & Employee \\
\hline \multirow{3}{*}{ Compound Cleaning } & Initiators & Danwei & Resident \\
\hline & Funding & Danwei & Resident \\
\hline & Participants & Employee, Resident & Resident \\
\hline \multirow{3}{*}{ Facility/Equipment Maintenance } & Initiators & Danwei & Resident \\
\hline & Funding & Danwei & Government \\
\hline & Participants & Employee & Employee \\
\hline \multirow{3}{*}{ Human Excreta Disposal } & Initiators & Danwei & - \\
\hline & Funding & - & - \\
\hline & Participants & Outsider & - \\
\hline
\end{tabular}

Due the 1997 Urban Housing reform, the ownership of the housing units in the AMS Danwei compound was distributed to the residents, while other estates such as office buildings and public facilities remained under the control of the AMS Danweis'. From the view of property rights, the management and maintenance of the compound became a joint responsibility and obligation of the AMS Danweis and the residents. However, the residents could not establish a neighbourhood organisation, legally and operationally, to continue compound management. Hence the residents and the government have to take over some of the management works after the reforms. Key residents revealed that with the decline of the Danweis' economic situation, the management and maintenance become chaotic since AMS Danweis could not provide competitive remuneration. As shown in Table 7 , in terms of facility maintenance and garbage collection, for example, the professionals employed by the Danwei's continued to handle maintenance activities, while whose funding is from the government after the reforms. Meanwhile, it is necessary to note that although Table 7 shows that post-reform compound cleaning was mainly carried out by the residents, this does not mean that the residents formed a community organisation to carry out regular or effective cleaning. In the field observation, it was found that residents only cleaned the compound randomly, with low frequency and intensity. This has led to the gradual deterioration of physical conditions inside the Danwei compound. Consequently, Government have taken over technical aspects of management and maintenance work in the AMS.

Figure 14 depicts the frequency on compound management activities by actors in Table 7 along a public-private spectrum. The most frequent management actor before the reforms was the 'Danwei', with six occurrences, and the most frequent after the reforms was the 'resident', with four occurrences. The Danwei, that once played an important role in the management of the compound have disappeared, and the management actors show a clear separation of public and non-public actors. 


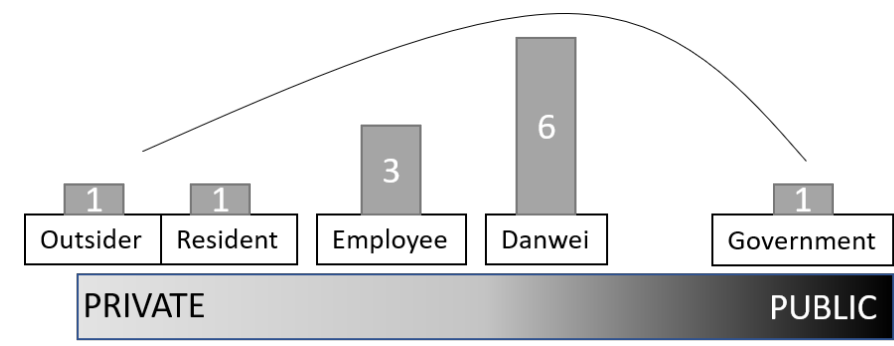

(a) Before the reforms

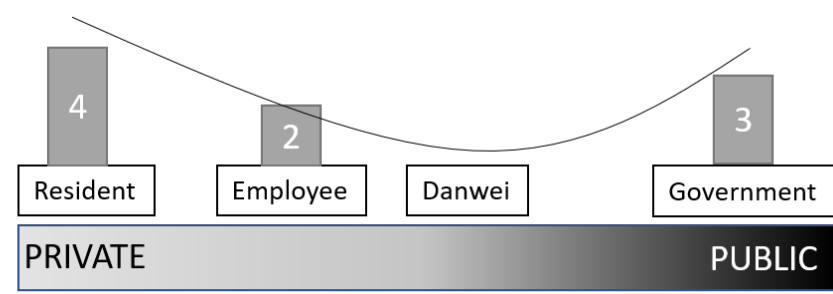

(b) After the reforms

Figure 14. The public-private spectrum of management actors.

\section{Discussion}

The findings of this study reveal the social and spatial aspects of changes in the evolution of urban neighbourhoods. In the context of old Chinese cities and emerging cities generally, the results correspond with the summary of major changes in socio-spatial schema in urban neighbourhood studies presented in Table 1, Section 2. Furthermore, by positioning the results within the framework in Figure 1, the study reveals how the dynamics of two major policy reforms influence socio-spatial changes at the urban neighbourhood level.

In terms of physical changes in the Danwei compound, the study found that after the reforms, the AMS Compound has lost most of its public space, gradually eroding the spatial context for urban public life. For example, the size of available physical space for public activities has declined from 25,870 square metres in 1975 to 8200 square metres in 2018. Indeed, the loss of public space has been widely recognised in recent urban development in China, and its causes are believed to be related to the end of communal land ownership system and the commercially driven land development process in a quasicapitalist framework, which significantly boosted the real estate developments in the city centre [37]. These kinds of reform driven spatial changes are similar to those reported in studies by He and their colleagues $[19,23]$ and in other Chinese cities such as Shanghai and Guangzhou. This situation could be detrimental to the quality of the neighbourhood living environment as studies show that public spaces are of high significance to urban residents' sense of belonging to a community and their self-evaluation of urban quality of life [38,39].

Another important finding is related to changes in boundary and density of the Danwei compound. Contrary to recent research [40-42] that point to outward physical expansion, especially in Asian and other cities in the emerging world, the AMS Danwei compounds have rather seen physical readjustments in land use and housing densification since 1999. As shown in Figure 2, the differences in socio-spatial changes between city level and urban neighbourhoods may be due to the fact that the impact of reforms on urban space are mediated by other economic forces such as the real-estate market and planning support systems. From an eco-city perspective [43], this could be a potentially positive spatial change if the dense and compact developments make room for mixed uses while the old neighbourhoods preserved for socio-spatial continuity. However, in the AMS compound our study only finds an increase in density, while the community function degenerated from a mixed-use one towards a purely residential one.

Relatedly, the analysis shows that shared or common use public facilities (e.g., shared tap water) that used to be the converging point for resident's interaction and social life (social groups) before the reforms have gradually disappeared. This phenomenon is similar to the case of Izmir, Turkey, studied by Eranil et al., where the introduction of high rise housing led to a reduction in social interaction among residents [22]. On the one hand, this marks improvements in indoor housing conditions after the Urban Housing Reform. On the other hand, they also suggest that the material components of the neighbourhood that support vibrant social and communal life have been lost. As earlier studies that show that shared use or the presence of common public facilities often contribute to social vibrancy in public or community spaces $[44,45]$, this warrants a call to action to define and identify 
new elements in the urban socio-spatial system that can enhance social and communal life of the compound.

In terms of social changes, two key issues were identified: compound management and usage of public space. These two topics correspond to the findings of Eranil et al. [22], Gür and Enön [20] and He [19]. With regards to compound management, the study findings show a major change of management actors in the Danwei compound. For example, before the reforms, the Danwei solely initiated, funded and employed personnel for compound maintenance and management activities (e.g., garbage collection, facility maintenance and cleaning). However, the reform-induced private house ownership and the decline of Danwei economic situation means compound management is now in the hands of Danwei employees, residents, and government-a much chaotic situation than before the reforms. This is contrary to some studies in the East Asian context which show that well organised communities and grassroot organisations can collaborate with public and private agencies to support better compound management, such as the Machinai-kai in Japan [46] and thus, should be given attention in improving compound maintenance and management activities. In the context of Danwei compound it suggests the need for a well-developed communication regime between the residents and the local government [47].

\section{Urban Planning Implications and Conclusions}

The study purposed to analyse social-spatial changes in the AMS Danwei compound in Hefei, China, via the situation before and after the 1978 Reform and Opening Up and the 1997 Urban Housing reform. Departing from existing research that indicates the decline in the Danwei compounds in old Chinese cities, the paper analysed the historical changes of the neighbourhood's socio-spatial schema and elements such as the physical space, the usage of public spaces and the management of the AMS compound as the research objects. This paper contributes to the existing body of knowledge through comparison of the social-spatial elements of a Danwei compound in the time domain. For the most part, findings show that while the decrease of public space, the increase of building density, the gradual functional shift from a work-life compatible neighbourhood to a purely residential one. On the other hand, the daily management and maintenance of the compound by the 'Danwei' has been replaced by the government and residents. These findings point to the degradation of public space and social life in the AMS compound after the reforms.

The results of this study exert three policy implications for the future planning of Danwei compounds. First, the need for supportive planning and design policies that improve the public realm of Danwei compounds. Clearly, that the decline of public space in the community represents declines in the quality of social life brought about by the former top-down reforms. Meanwhile, the reorientation of the site edge pattern and the high density development of the AMS Danwei compound show the positive side of the development of this urban community. However, the lack of early planning intervention has led to a loss of community function and a failure to create a mixed-use community. This calls for targeted interventions in urban design principles that make room for public facilities and public spaces such as shops, neighbourhood parks and walking system. In a post COVID-19 urban environment, this can encourage enrich the residents' time spent in the neighbourhood and overall community life.

Second, planners need to understand, analyse and integrate the special needs of Danwei residents in order to plan for them appropriately. This implies opening up the planning and design process to factor the needs and aspirations of residents in the old city core, where most residents reside in Danwei compounds. Additionally, it invites the local government to avoid over-concentration of development of outer areas to improve social and spatial quality inner areas of the old city core. This paper recommends structural improvements in the city and regional planning, such as creating more efficient nonmotorised transport facilities or implementing more compact city planning principles.

Third, rebuilding local community organisation with resident participation. This measure could lead to the increasing of the communication intensity between residents, the 
improvement of basic community services and management capacity. Such organisation could also act as an intermediary layer between residents and the government. This organisation can take the form of an homeowners' or tenants' committee organised by the residents, or a primary administrative service team facilitated by the government, or a combination of these two.

In spite of the findings and contributions above, this study has some limitations. First, the restricted sample size of key person interviews is relatively small, and might not account for the general situation of the Danweis other than the AMS compound. Second, the object of this study is limited to the socio-spatial elements within a single Danwei compound, lacking comparisons with other compounds and non-Danwei settlements. Moreover, from a dialectical point of view, the findings of this paper seem to indicate that the two reforms only had a negative impact on the Danwei compound. However, besides the socio-spatial environment inside the Danwei compounds, they had obvious positive effects on other aspects such as social economy, freedom of the people and indoor housing conditions. This study, therefore, provides an entry point for future directions such as comparative studies of the socio-spatial environment of other Danwei and non-Danwei residential sites and an integration of economic and other structural components.

Author Contributions: Conceptualization, N.Y., M.K., S.M., M.S., and S.A.O.; methodology, N.Y., M.K. and S.A.O.; software, N.Y.; validation, N.Y., M.K., S.M., M.S., and S.A.O.; formal analysis, N.Y.; investigation, N.Y.; resources, N.Y., and S.M.; data curation, N.Y.; writing-original draft preparation, N.Y., S.A.O.; writing-review and editing, N.Y., S.A.O. and M.K.; visualization, N.Y. and M.S.; supervision, N.Y., S.A.O. and M.K.; project administration, N.Y. All authors have read and agreed to the published version of the manuscript.

Funding: This research received no external funding.

Data Availability Statement: Data available in a publicly accessible repository.

Conflicts of Interest: The authors declare no conflict of interest.

\section{Abbreviations}

The following abbreviations are used in this manuscript:

PRC People's Republic of China

AMS Anhui Academy of Medical Science

\section{References}

1. Skocpol, T. States and Social Revolutions: A Comparative Analysis of France, Russia and China/Theda Skocpol; Cambridge University Press: Cambridge, UK, 1979.

2. Bray, D. Social Space and Governance in Urban China: The Danwei System from Origins to Reform/David Bray; Stanford University Press: Stanford, CA, USA, 2005.

3. $\mathrm{Wu}, \mathrm{H}$. The Danwei Tradition in Chinese Organizational Identification and Its Modern Changes. J. Soc. Sci. Hunan Norm. Univ. 2016, 45, 49-56. (In Chinese)

4. Fang, C.-L. The urbanization and urban development in China after the reform and opening-up. Econ. Geogr. 2009, $29,19-25$.

5. Wen, T. The Eight Crises: China's Real Experience 1949-2009; The Oriental Press: Beijing, China, 2013. (In Chinese)

6. Liu, J. Danwei China; Tianjin People's Publishing House: Tianjing, China, 2000. (In Chinese)

7. Tian, Y. Changes in the "Danwei Community" and Urban Community Renewal, 1st ed.; National Achievements Library of Philosophy and Social Sciences, Central Compilation \& Translation Press: Beijing, China, 2014. (In Chinese)

8. Li, J.; Dai, S. 60 years of urban land-use system reform in China: A review and outlook. Rev. Econ. Res. 2009, 63, 2-10.

9. Zhang, C.; Chai, Y. The Residential Residual in Danwei Community and Its Impact Factor. Urban Plan. Int. 2009, 24, 15-19. (In Chinese)

10. Tanigawa, S. The origin of the "Danwei" system in Anti-Japanese Base Area. Asian Stud. 1999, 44, 67-106. (In Japanese) [CrossRef]

11. Bian, M.L. The Making of the State Enterprise System in Modern China: The Dynamics of Institutional Change; Harvard University Press: Cambridge, MA, USA; London, UK, 2005.

12. Zhou, Y.; Yang, X. China Danwei System; China Economic Publishing House: Beijing, China, 2002. (In Chinese)

13. Peiling, Z. A socio-economic-cultural exploration on open space form and everyday activities in Danwei: A case study of Jingmian compound, Beijing. Urban Des. Int. 2014, 19, 22-37. [CrossRef] 
14. Zhang, C.; Chai, Y.; Zhou, Q. The Spatiality and Spatial Changes of Danwei Compound in Chinese Cities: Case Study of Beijing No.2 Textile Factory. Urban Plan. Int. 2009, 24, 20-27. (In Chinese)

15. Ye, N.; Kita, M.; Matsubara, S.; Okyere, S.A.; Shimoda, M. A Study of the Spatial Distribution of Danwei Compounds in the Old Town of Hefei, China. Urban Sci. 2021, 5, 7. [CrossRef]

16. Ye, N.; Wang, B.; Kita, M.; Xie, M.; Cai, W. Urban Commerce Distribution Analysis Based on Street View and Deep Learning. IEEE Access 2019, 7, 162841-162849. [CrossRef]

17. Lee, T. Urban Neighbourhood as a Socio-Spatial Schema. Hum. Relat. 1968, 21, 241-267. [CrossRef]

18. Wang, Y.; Liu, K. Evolution of Urban Socio-Spatial Structure in Modern Times in Xi'an, China. Sustainability 2017, 9, 1935. [CrossRef]

19. He, S. Evolving enclave urbanism in China and its socio-spatial implications: The case of Guangzhou. Soc. Cult. Geogr. 2013, 14, 243-275. [CrossRef]

20. Öymen Gür, S.; Enön, Z. Changing socio-Spatial aspects of neighborhood: Design implications. Ekistics 1990, 57, 138-145.

21. Sykora, L. Processes of Socio-spatial Differentiation in Post-communist Prague. Hous. Stud. 1999, 14, 679-701. [CrossRef]

22. Eranıl Demirli, M.; Tuna Ultav, Z.; Demirtaş-Milz, N. A socio-spatial analysis of urban transformation at a neighborhood scale: The case of the relocation of Kadifekale inhabitants to TOKİ Uzundere in İzmir. Cities 2015, 48, 140-159. [CrossRef]

23. He, S.; Wu, F. Socio-spatial impacts of property-led redevelopment on China's urban neighbourhoods. Cities 2007, 24, 194-208. [CrossRef]

24. Li, Z.; Wu, F. Socio-spatial Differentiation and Residential Inequalities in Shanghai: A Case Study of Three Neighbourhoods. Hous. Stud. 2006, 21, 695-717. [CrossRef]

25. Hefei Planning Bureau. Hefei Urban Planning Record; HuangShan Books: Hefei, China, 2013.

26. Hefei City Statistics Bureau. Hefei City 2019 National Economic and Social Development Statistics Bulletin. 2020. Available online: http:/ / tjj.hefei.gov.cn/tjyw / tjgb/14578501.html (accessed on 2 December 2020).

27. Hefei Local Gazetteers Compilation Committee. Local Gazetteers of Hefei; Anhui Sheng Di Fang Zhi Cong Shu, Anhui Peoples Publishing House: Hefei, China, 1999.

28. National Bureau of Statistics. Annual Demographic Data for China. 2019. Available online: https://data.stats.gov.cn/easyquery. $\mathrm{htm} ? \mathrm{cn} \backslash \backslash=\mathrm{C} 01 \& \mathrm{zb}=\mathrm{A} 0301 \& \mathrm{sj}=2019$ (accessed on 14 October 2020).

29. Byrne, M.M. Evaluating the findings of qualitative research. AORN J. 2001, 73, 703-706. [CrossRef]

30. Okumah, M.; Martin-Ortega, J.; Chapman, P.J.; Novo, P.; Cassidy, R.; Lyon, C.; Higgins, A.; Doody, D. The role of experiential learning in the adoption of best land management practices. Land Use Policy 2021, 105, 105397. [CrossRef]

31. Aptekar, S. Looking Forward, Looking Back: Collective Memory and Neighborhood Identity in Two Urban Parks. Symb. Interact. 2017, 40, 101-121. [CrossRef]

32. Jeanneret Brith, F.J.; Reyes Andreani, M.J.; Cruz Contreras, M.A.; Castillo Vega, C.M.; Jeanneret Brith, J.E.; Pavez Pérez, J.F.; Badilla Rajevic, M. Joint action as a practice of memory transmission in a poor urban neighborhood of Santiago, Chile. J. Community Psychol. 2021, 49, 58-76. [CrossRef]

33. Thomas, J.M. Neighborhood Planning: Uses of Oral History. J. Plan. Hist. 2004, 3, 50-70. [CrossRef]

34. Hallowell, G.; Baran, P. Neighborhood Dynamics and Long-Term Change. Geogr. Anal. 2020. [CrossRef]

35. Bendjedidi, S.; Bada, Y.; Meziani, R. Urban plaza design process using space syntax analysis. Int. Rev. Spat. Plan. Sustain. Dev. 2019, 7, 125-142. [CrossRef]

36. Garau, C.; Annunziata, A.; Yamu, C. A walkability assessment tool coupling multi-criteria analysis and space syntax: The case study of Iglesias, Italy. Eur. Plan. Stud. 2020, 1-23. [CrossRef]

37. Wang, F. Streets and Lanes. disP Plan. Rev. 2017, 53, 45-49. [CrossRef]

38. Francis, J.; Giles-Corti, B.; Wood, L.; Knuiman, M. Creating sense of community: The role of public space. J. Environ. Psychol. 2012, 32, 401-409. [CrossRef]

39. Bonaiuto, M.; Fornara, F.; Bonnes, M. Indexes of perceived residential environment quality and neighbourhood attachment in urban environments: A confirmation study on the city of Rome. Landsc. Urban Plan. 2003, 65, 41-52. [CrossRef]

40. Abu Hatab, A.; Cavinato, M.E.R.; Lindemer, A.; Lagerkvist, C.J. Urban sprawl, food security and agricultural systems in developing countries: A systematic review of the literature. Cities 2019, 94, 129-142. [CrossRef]

41. Coq-Huelva, D.; Asián-Chaves, R. Urban Sprawl and Sustainable Urban Policies. A Review of the Cases of Lima, Mexico City and Santiago de Chile. Sustainability 2019, 11, 5835. [CrossRef]

42. Wang, X.; Shi, R.; Zhou, Y. Dynamics of urban sprawl and sustainable development in China. Socio-Econ. Plan. Sci. 2020, 70, 100736. [CrossRef]

43. Roseland, M. Dimensions of the eco-city. Cities 1997, 14, 197-202. [CrossRef]

44. Tumlin, J. Sustainable Transportation Planning: Tools for Creating Vibrant, Healthy, and Resilient Communities; John Wiley \& Sons: Hoboken, NJ, USA, 2012; Volume 16.

45. Lu, S.; Huang, Y.; Shi, C.; Yang, X. Exploring the Associations Between Urban Form and Neighborhood Vibrancy: A Case Study of Chengdu, China. ISPRS Int. J. Geo-Inf. 2019, 8, 165. [CrossRef]

46. Nishimoto, Y. Friendly Authoritarianism and Neighborhood Associations in Rural Japan-A Case from Noto Peninsula. Bull. Fac. Hum. Sci. Kanazawa Univ. 2018, 1-24.

47. Tian, Y. The Pain of Urban Social Management in China in Transition-An Analytical Perspective on Social Atomisation. Explor. Free Views 2012. (In Chinese) [CrossRef] 